\title{
Sculptural Variation of the Pliocene \\ Pelecypod Patinopecten healeyi (Arnold)
}

GEOLOGICAL SURVEY PROFESSIONAL PAPER 1103
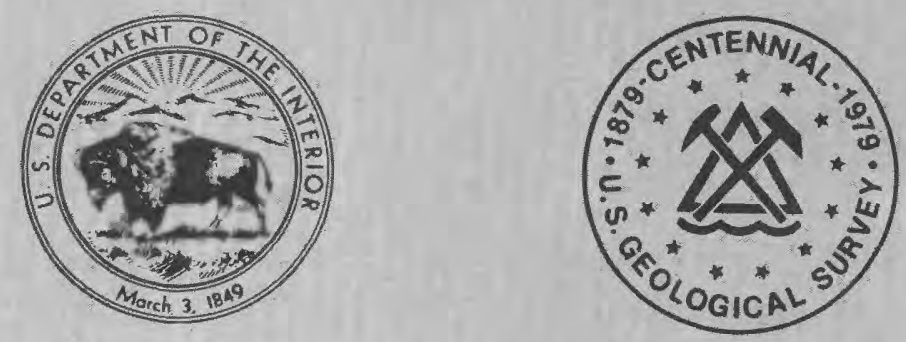


\title{
Sculptural Variation of the Pliocene \\ Pelecypod Patinopecten healeyi (Arnold)
}

\author{
By ELLEN JAMES MOORE
}

G E O L O G I C A L S U R V E Y PROFES S I O A L P A PE R 11103

Primary sculpture and microsculpture described

and illustrated; includes stratigraphic occurrence and ecology

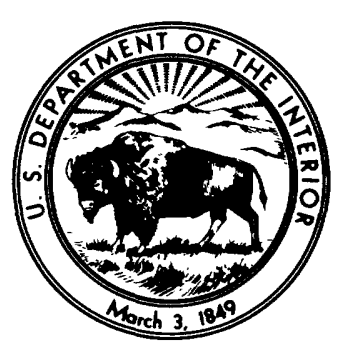

UNITEDSTATES GOVERNMENT PRINTING OFFICE, WASHINGTON: 1979 
UNITED STATES DEPARTMENT OF THE INTERIOR

CECIL D. ANDRUS, Secretary

\section{GEOLOGICAL SURVEY}

H. William Menard, Director

\footnotetext{
Library of Congress Cataloging in Publication Data

Moore, Ellen James.

Sculptural variation of the Pliocene pelecypod Patinopecten healeyi (Arnold)

(Geological Survey professional paper ; 1103)

Bibliography: p. 12-13.

Includes index.

Supt. of Docs. no.: I 19.16:1103

1. Patinopecten healeyi. 2. Paleontology-Pliocene. 3. Paleontology-

California. I. Title. II. Series: United States. Geological Survey.

Professional paper ; 1103.

QE812.P4M66

$564^{\prime} .11$

$79-607097$
}

For sale by the Superintendent of Documents, U.S. Government Printing Office Washington, D.C. 20402

Stock Number 024-001-03225-2 


\section{CONTENTS}

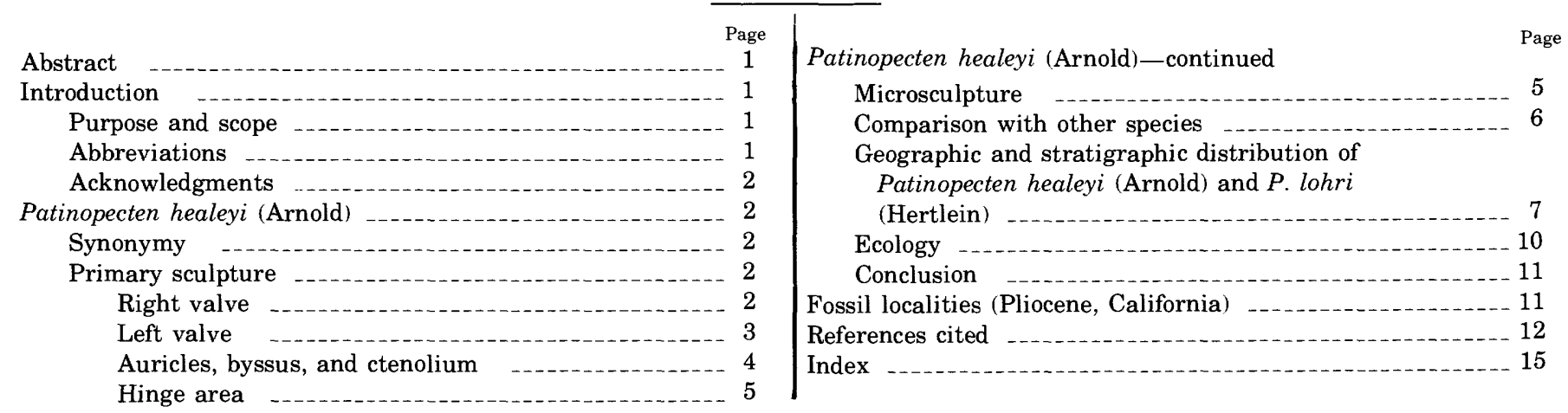

\section{ILLUSTRATIONS}

Plates 1-12. Patinopecten healeyi (Arnold).

[Plates follow index]

13. Patinopecten lohri (Hertlein) and Patinopecten healeyi (Arnold).

14, 15. Patinopecten yessoensis (Jay) and Patinopecten healeyi (Arnold).

Figure

1. Index map showing geographic distribution of Patinopecten healeyi (Arnold) and Patinopecten lohri (Hertlein) 



\title{
SCULPTURAL VARIATION OF THE PLIOCENE PELECYPOD PATINOPECTEN HEALEYI (ARNOLD)
}

\author{
By Ellen James Moore
}

\begin{abstract}
The sculptural variation of both right and left valves of Patinopecten healeyi (Arnold) is more extreme than has been generally known and has led to difficulty in distinguishing $P$. healeyi from other species, especially Patinopecten lohri (Hertlein) and even in the identification of the species itself. Variants of this common Pliocene species, which occurs in California and Baja California, include a smooth form with subdued dichotomous ribs on the right valve and closely spaced, fine ribs on the left valve with some intercalaries that are as wide as the primary ribs; right valves with flat, widely spaced, dichotomous ribs and right valves with high, rounded, closely spaced, dichotomous ribs; and left valves with high square ribs and rounded intercalaries and left valves with smooth interspaces and no intercalaries.

Scanning electron micrographs of the imbricated microsculpture that is found only on left valves of $P$. healeyi show the development of this sculpture. The same microsculpture is present on both the left and the right valves of the living species Patinopecten yessoensis (Jay) of Japan. When more data are available, this microsculpture may prove to be taxonomically significant.

$P$. healeyi is generally more common in southern California than $P$. lohri and occurs as far south as Vizcaino Peninsula, Baja California.

Ecological data concerning the closely related living species Patinopecten caurinus (Gould) include the observations that it lives at depths of 15 to $275 \mathrm{~m}$, is not an active swimmer, is byssally attached until it has grown to about $4 \mathrm{~cm}$ in shell diameter, and that its predators are Octopus, the large sun-star Pycnopodia, and crabs.
\end{abstract}

\section{INTRODUCTION \\ PURPOSE AND SCOPE}

The problem of identifying sculptural variants of Patinopecten healeyi (Arnold) became apparent when specimens of right valves of this species that on cursory inspection looked like Amusium were found in unnamed Pliocene strata on San Clemente Island, Calif. (Vedder and Moore, 1976). This form has now been named Patinopecten healeyi sanclementensis by Suzuki and Stadum (1978).

Patinopecten healeyi (Arnold) was originally described from the San Diego Formation (Pliocene), Pacific Beach, Calif., as Pecten expansus Dall (1878, p. 14) but later renamed Pecten (Patinopecten) healeyi Arnold (1906, p. 103-105, pl. 36, figs. 1, 1a; pl. 37, figs. 1, 1a, 2) because the older name was preoccupied. Although variation in the sculpture of $P$. healeyi has been noted (Arnold, 1906, p. 103-105; Woodring and Bramlette, 1950, p. 84; Hertlein and Grant, 1972, p. $185)$, the variation is more diversified than has been generally understood. Right valves that are smooth to a height of $30 \mathrm{~mm}$ have been figured (Hertlein and Grant, 1972, pl. 33, fig. 9; pl. 36, fig. 9), but none so large as those collected from San Clemente Island (pl. 2, figs. 3-7), from unnamed Pliocene strata, had been previously illustrated (Suzuki and Stadum, 1978). In addition to the smooth form, the right-valve sculpture varies from flat, widely spaced, dichotomous ribs that become obsolete near the ventral margin to high, rounded, closely spaced, dichotomous ribs. The leftvalve sculpture ranges from closely spaced, fine ribs of nearly equal size to high, wide, flat square ribs alternating with one or two rounded secondary ribs. These extremes in sculptural variation have not been clearly illustrated or described, and this range of variation has led to confusion between named species.

Comparisons made with the similar species Patinopecten lohri (Hertlein), with which $P$. healeyi has been confused, include geographic and stratigraphic distribution. Observations on the habitat of the closely related Holocene species Patinopecten caurinus (Gould) concern depth of occurrence, swimming, attachment, and predators. Scanning electron micrographs of the imbricated microsculpture of $P$. healeyi show its development, which may prove to be useful taxonomically.

Approximately 400 specimens of Patinopecten healeyi from the San Diego Formation and about 100 each from the Fernando Formation in the Newport Beach area and the Niguel Formation in the San Juan Capistrano area were examined in the course of this study.

ABBREviations
CAS-California Academy of Sciences, San Francisco,
Calif.
LAM-Natural History Museum of Los Angeles
County, Los Angeles, Calif.
SU-Stanford University, Stanford, Calif. [These


types are now deposited in the California Academy of Sciences.]

UCMP-University of California Museum of Paleontology, Berkeley, Calif.

USGS-M-U.S. Geological Survey, Menlo Park, Calif., Cenozoic locality register.

USNM-National Museum of Natural History,

Washington, D.C.

\section{ACKNOWLEDGMENTS}

John G. Vedder, U.S. Geological Survey, provided specimens of Patinopecten healeyi (Arnold) that he had collected from Pliocene strata in southern California and furnished stratigraphic information. F. R. Bernard, Pacific Biological Station, Nanaimo, British Columbia, kindly provided information on the living habits of Patinopecten caurinus (Gould). Barry Roth, California Academy of Sciences, searched the Academy collections and loaned specimens of $P$. healeyi. Judith T. Smith, Palo Alto, California, Louie Marincovich, Jr., U.S. Geological Survey, and J. W. Durham, University of California, assisted with discussions and the loan of specimens. W. O. Addicott, U.S. Geological Survey, and T. R. Waller, Smithsonian Institution, read the manuscript and improved its technical quality.

The scanning electron micrographs were taken by Robert Oscarson, the photographs by Kenji Sakamoto, both of the U.S. Geological Survey, and I thank them for their patience and attention to detail.

To E. C. Wilson, Curator, Natural History Museum of Los Angeles County, Los Angeles, Calif., I express my special gratitude for the loan of about 400 specimens of $P$. healeyi from the San Diego Formation and for other courtesies he graciously extended to me.

\section{PATINOPECTEN HEALEYI (ARNOLD)}

Pecten expansus Dall, 1878, U.S. Natl. Mus. Proc., v. 1 , p. 14 [1879].

Not Pecten expansus Smith, 1847, Geol. Soc. London

Quart. Jour., v. 3, p. 413, 419, pl. 18, fig. 21.

Pecten (Patinopecten) expansus Dall, 1898, Wagner Free Inst. Sci. Trans., v. 3, pt. 4, p. 706, pl. 26, fig. 1. Arnold, 1903, California Acad. Sci. Mem., v. 3, p. 108.

Pecten (Patinopecten) healeyi Arnold, 1906, U.S. Geol. Survey Prof. Paper 47, p. 103, pl. 36, figs. 1, 1a; pl. 37, figs. 1, 1a, 2. Arnold and Anderson, 1907, U.S. Geol. Survey Bull. 322, p. 154, pl. 26, figs. 1, 2. Grant and Gale, 1931, San Diego Soc. Nat. History Mem., v. 1, p. 196, pl. 6, figs. 2a, 2b. Hertlein and Grant, 1972, San Diego Soc. Nat. History Mem. 2 (pt. 2b), p. 183-185, pl. 31, figs. 1, 4, 6, 7; pl. 33, fig. 9 ; pl. 36 , figs. 8,9 ; text fig. 9 .
Patinopecten healeyi (Dall), Vedder and Moore, 1976, p. 122 , pl. 3 , figs. $2-6,8$.

Pecten (Patinopecten) healeyi Arnold sanclementensis Suzuki and Stadum, 1978, Nat. Hist. Mus., Los Angeles Co., Contrib. Sci. 299, p. 10-11, figs. 18, 19. Holotype._USNM 148012.

Type locality. - San Diego Formation (Pliocene), San Diego County, Calif.

A complete synonymy is given in Hertlein and Grant (1972, p. 183-184). The elevation of Patinopecten to generic rank does not make it possible to use the specific name expansus for this species, because Pecten expansus Dall is a junior primary homonym.

\section{PRIMARY SCULPTURE}

\section{RIGHT VALVE}

Plate 1, figures 1-4, 6-8; plate 2, figures $1-3,5-7$; plate 3 , figures $1-6$; plate 4 , figures $1-4,8$; plate 14 , figure 3

The typical sculpture of the right valve (Arnold, 1906, p. 103-105; Hertlein and Grant, 1972, p. 185) consists of 18 to 21 prominent squarish, subequal ribs that branch to become dichotomous and on a few individuals trichotomous, after 30 to $40 \mathrm{~mm}$ in height (pl. 1, fig. 1). The medial sulcus of the rib may be as deep as the interspace, completely dividing the primary rib. The interspaces are subequal, much narrower than the ribs, deeply channeled, and on some specimens ornamented by a small rounded intercalary riblet.

Patinopecten healeyi is easily recognized by the flat-topped sulcated radial ribs on the right valve. Juvenile specimens are smooth in the early stage; radial undulations of the anterior margin typically begin to form after the shell has attained a height of 3 to $5 \mathrm{~mm}$ (pl. 1, figs. 4,6). Some specimens remain smooth to a height of $23 \mathrm{~mm}$. The ribs on the right valve, especially those toward the anterior and posterior margins, begin to develop a slight medial sulcus after the shell has attained a height of $10 \mathrm{~mm}$, but such sulcations on the medial ribs are well developed only after a height of 30 to $40 \mathrm{~mm}$ has been attained. The ribs on some large specimens bear two sulcations that divide the major ribs into three small riblets, but such forms, so far as known, have no taxonomic significance (Hertlein and Grant, 1972, p. 185). A narrow unsculptured band may be present at the anterior and posterior margins, usually wider at the posterior side (pl. 1, fig. 8)

A smooth form of $P$. healeyi (pl. 2, figs. 3-7) that tends to be relatively thin shelled occurs only in unnamed Pliocene strata on San Clemente Island, southern California (Vedder and Moore, 1976, p. 122, p1. 3, figs. 2-6, 8; Suzuki and Stadium, 1978, figs. 18, 19). A fragment of a large right valve shows the disk 
to be smooth to about $30 \mathrm{~mm}$, at which point strong dichotomous ribs with very narrow interspaces appear (p1. 2, fig. 3). An incomplete right valve that is nearly $100 \mathrm{~mm}$ high has the disk smooth in the midportion of the shell to a height of about $40 \mathrm{~mm}$, the rest of the shell being sculptured by very low, closely spaced, dichotomous and trichotomous ribs (p1. 2, fig. 7). A large incomplete worn right valve, originally more than $145 \mathrm{~mm}$ long, has a smooth disk to a height of 55 $\mathrm{mm}$ and shows subdued dichotomous ribs near the posterior margin; the largest specimen obtained was about $160 \mathrm{~mm}$ high with the hinge about $75 \mathrm{~mm}$ long. A small complete right valve that is $50 \mathrm{~mm}$ high is essentially smooth; traces of the same rib pattern seen on the other right valves from San Clemente Island are visible in low-angle reflected light (p1. 2, fig. 6). These smooth right valves have a wide unsculptured band at both the anterior and posterior margins (p1. 2 , figs. 3,7 ).

Three right valves from the San Diego Formation at Pacific Beach, Calif. (CAS 105, 547), have a smooth disk to a height of $20 \mathrm{~mm}$ and ribs somewhat subdued for an additional interval of about $10 \mathrm{~mm}$ (p1. 2, fig. 1); one right valve (CAS 105) has closely spaced low ribs that are not dichotomous on the midportion of the shell (p1. 2, fig. 2).

Woodring (in Woodring and Bramlette, 1950, p. 84) noted that the interspaces on many right valves of $P$. healeyi from the Santa Maria basin are much narrower than the interspaces on right valves of $P$. healeyi from the San Diego Formation and that the right valves are more inflated. A few specimens from collections now available from the San Diego Formation show this same sculpture and valve inflation (pl. 3 , figs. 1, 5), as do some individuals from the Niguel Formation (pl. 3, fig. 4) of Pliocene age in the San Juan Capistrano quadrangle (USGS M2096, M2098).

In one collection from the Fernando Formation (Pliocene), in the Newport Beach quadrangle (USGS M2753), right valves with dichotomous and trichotomous ribs (pl. 4, fig. 2), right valves with narrow rather subdued ribs (pl. 4, fig. 1), and right valves with smooth disks to a height of about $50 \mathrm{~mm}$ followed by low subdued ribs (pl. 4, fig. 4), occur together. In another collection from the same area (USGS M5040), fragments of right valves include the smooth form (pl. 3 , fig. 2), some with narrow, widely spaced, dichotomous ribs (pl. 3, fig. 6), and others with very closely spaced, dichotomous and trichotomous ribs (pl.3, fig. 3 ). On some specimens of right valves from this locality, there is no unsculptured band at the posterior shell margin.

The right valve of $P$. healeyi may extend as much as $10 \mathrm{~mm}$ beyond the left valve along the entire distal margin of the disk (p1. 6, fig. 7). A similar difference between valves has been noted on Patinopecten caurinus (Gould), the Holocene genotype of Patinopecten, which has been collected from sedimentary rocks as old as Pliocene (Grau, 1959, p. 147; Moore, 1963, p. 63).

LEFT VALVE

Plate 2 , figure 4 ; plate 4 , figure 5 ; plate 5 , figures $1-3,6$; plate 6 , figures 3,7 ; plate 7 , figures $1,2,4,5$; plate 8 , figures $1,3,4,6$; plate 9 , figures 4,7 ; plate 10 , figures $1,3,4$; plate 15 , figure 3

Arnold (1906, p. 103-105) described the left valve of $P$. healeyi as much compressed and the ribs as narrow and rounded on some individuals with a narrow peak along which there may be a narrow, slightly raised line. The interspaces are wide and each is ornamented by a more or less prominent, rounded intercalary riblet.

Although the typical left valve sculpture has been described as primary ribs with interspaces invariably bearing a secondary rib (Arnold, 1906, p. 104; Hertlein and Grant, 1972, p. 185), it is common to find specimens that have a few smooth interspaces without a secondary rib, and even specimens with no secondary ribs are occasionally found (p1. 5, fig. 2). The left valve may bear 17 to 21 primary ribs; 18 is the most common number. The umbonal angle, measured on the disk between ears, is between $110^{\circ}$ and $120^{\circ} ; 115^{\circ}$ is the most common, and on inequilateral specimens with a very enlarged anterior ear, $120^{\circ}$.

The left-valve sculpture of specimens of $P$. healey $i$ from the San Diego Formation ranges from narrow rounded ribs with wide interspaces that each bear a fine intercalary riblet (pl. 5, fig. 1) to wide square ribs that may bear a fine rib along the top (pl. 8, fig. 1) and that may have some interspaces that do not bear an intercalary. The square-ribbed forms typically begin with a sculpture of narrow rounded ribs that become flat when the shell reaches a height of about 60 $\mathrm{mm}$ (p1. 6, fig. 4). On some square-ribbed forms, the intercalaries are fine and rounded (p1. 7, fig. 5); on others, the intercalaries, though rounded, are much wider (pl. 8, fig. 4). On some left valves, the ribs tend to become obsolete near the ventral margin (p1. 9, fig. 7), a feature seen on $P$. caurinus (Moore, 1963, p. 65). Some left valves are markedly thinner than others that bear the same primary rib pattern.

Left valves from the Niguel Formation (Pliocene) in the San Juan Capistrano quadrangle (USGS M2096, M2098) show the same marked variation of narrow rounded ribs to square flat ribs as seen on specimens from the San Diego Formation. One fragment of a large left valve has two secondary ribs (or a split secondary) between the primary ribs near the anterior margin (p1. 9, fig. 4). 
Left valves in a collection (USGS M2753) from the Fernando Formation (Pliocene) in the Newport Beach quadrangle include one fragment with multiple secondary ribs at the anterior margin (pl. 7, fig. 2).

Four left valves were collected from unnamed Pliocene strata on San Clemente Island (USGS M6503) with right valves of the smooth form. Although no articulated specimens were found, it is assumed that these left valves represent the smooth form. The ribs are unusually fine, narrow, and a bit more closely spaced than is common; some of the intercalaries are as wide as the primary ribs (p1. 5, fig. 3 ). One of these left valves is about $160 \mathrm{~mm}$ high.

On some left valves, the shell curves upward along the ventral margin away from the soft parts, perhaps in response to pressure from the larger right valve. On most specimens, this extension of the left valve is exceptionally thin and ribs are obsolete; the extension is rarely preserved and may be more common than its preservation indicates.

In his discussion of the Argopecten gibbus stock, Waller (1969, p. 31) stated that

In the description of plicae, only features of the right valve are discussed because the interlocking of plicae along the distal margin produces a complimentarity***. Thus plicae that are distinctly broader than the interspaces on the right valve will likely be distinctly narrower than the interspaces on the left valve.

Grant and Gale (1931, p. 192), in their description of Patinopecten, stated that the left valve will have intercalaries if the right valve primary ribs are dichotomous.

In the course of this study, I have found that if the right-valve primary ribs are strongly dichotomous, in essence producing another interspace, the usual leftvalve response is to produce a strong secondary rib about equal in size to that of the space produced by the dichotomy. On these left valves, the primary ribs will be larger than average and square rather than rounded. If the right-valve disk is smooth and followed by low primary ribs that are only shallowly dichotomous, the left valve will usually respond with small rounded primaries and with secondaries of nearly equal size. On articulated specimens, one can usually predict the sculpture of either valve by simply examining the opposing valve.

Variation in the sculpture of Holocene specimens of Patinopecten caurinus (Moore, 1963, p. 63-65) is not as extreme as seen on $P$. healeyi. The ribs on the right valves of large specimens of $P$. caurinus may become obsolete near the margins, as may the ribs on large left valves. Fine intercalaries are irregularly spaced on parts of the left valve. On some individuals, intercalaries are occasionally present on the right valve but without a regular pattern or spacing.
AURICLES, BYSSUS, AND CTENOLIUM

Plate 1, figures 5, 6; plate 4, figures 6 , 7; plate 5 , figure 5 ; plate 6 , figures 1,2 ; plate 7 , figure 3 ; plate 13 , figures 1,2 ; plate 15 , figure 2

The right anterior auricle (ear) is slightly longer than the left anterior auricle, arcuate in front, and ornamented by several faint radial ridges; the byssal notch is prominent. The posterior auricle is slightly obliquely truncated and ornamented by sharp incremental lines and, on some specimens, by obsolete radiating ridges. The left-valve auricles are obliquely truncated and similarly sculptured (Arnold, 1906, p. 104).

On large specimens (p1. 14, fig. 3), the left anterior auricle is larger than the right anterior auricle. The byssal notch is convexly folded and elevated above the rest of the auricle (p1. 7, fig. 3; p1. 13, fig. 1), a feature noted on $P$. caurinus, and the left anterior auricle is concavely folded toward the right, opposite the byssal notch, bringing the auricles closer together (p1. 6, figs. 1,$2 ; \mathrm{p} 1.13$, fig. 2). The fold on the left anterior auricle typically becomes more pronounced as the shell grows larger such that on very large specimens the byssal opening is nearly closed.

Strong evidence suggests that the byssus on $P$. healeyi was functional at least during the early stages of growth. Several specimens, generally of small size, have been found that show a well-developed ctenolium (comblike row of teeth) below the anterior auricle (p1. 1 , figs. 5,6 ; p1. 4, figs. 6,7 ); others have been seen that are large in size with the shell corroded in such a way as to show the ctenolium along the entire attachment margin of the auricle. The presumed function of the ctenolium is to separate the byssal threads and keep them from twisting (Dall, 1898, p. 691). Waller $(1969$, p. 20$)$, noting that the presence of a ctenolium is correlated with the presence of a deep byssal notch, assumed that a deep byssal notch indicates the presence of a byssus or, for earlier growth stages, an active extrudible foot. Dall $(1898$, p. 691) said that the growth of the margin of the valve and auricle does not always coincide with the development of the ctenolium and that a species that normally shows this feature may have stages when the valve margin has grown over the old ctenolial set and the new set has not yet formed.

\section{Waller (1972a, p. 245) later stated}

***the absence of a ctenolium and byssal gape on mature shells indicates that the species may lie free at this stage rather than attach bysally. Young individuals, which have a distinct ctenolium and byssal gape, are probably bysally attached.

The ctenolium is present on small specimens of $P$. healeyi and is well developed, which probably indicates that it was not an obsolete character during the early stages of growth when the byssal opening was of 
good size and not yet almost completely closed by the enlarged, strongly folded left anterior ear. The Holocene species Patinopecten caurinus is byssally attached in early life to a size of about 3 to $4 \mathrm{~cm}$ in shell diameter; above this size the byssus is no longer present (F. R. Bernard, written commun., 1976).

The left-valve anterior auricle of $P$. healeyi may be higher as well as longer than the posterior auricle (p1. 5, fig. 5 ; p1. 6, fig. $1 ;$ p1 7, fig. 5; p1. 8, fig. 6). Marked enlargement of the left anterior auricle, typically characteristic of large specimens, is seen on some juvenile shells (p1. 10, fig. 3). The enlargement is generally coincident with the increased flexure of the auricle and the resultant closing of the byssal gap. Some examples of the difference in size between left-valve auricles are:
Anterior auricle

$23 \mathrm{~mm}$ long and $20 \mathrm{~mm}$ high $34 \mathrm{~mm}$ long and $22 \mathrm{~mm}$ high $35 \mathrm{~mm}$ long and $27 \mathrm{~mm}$ high $38 \mathrm{~mm}$ long and $27 \mathrm{~mm}$ high $44 \mathrm{~mm}$ long and $27 \mathrm{~mm}$ high
Posterior aurccle

$20 \mathrm{~mm}$ long and $13 \mathrm{~mm}$ high $27 \mathrm{~mm}$ long and $9 \mathrm{~mm}$ high $30 \mathrm{~mm}$ long and $19 \mathrm{~mm}$ high $32 \mathrm{~mm}$ long and $18 \mathrm{~mm}$ high $37 \mathrm{~mm}$ long and $19 \mathrm{~mm}$ high
On complete specimens, the difference in length of right-valve auricles is found to be about the same as the left-valve auricles, but the height of the rightvalve auricles remains equal.

\section{HINGE AREA}

Plate 1, figure 5; plate 6, figures 4-6; plate 8 , figures 2, 5; plate 9, figures $1-3,5,6$; plate 10 , figure 2

The resilial pit on the right valve is bordered on each side by a narrow, sharp, projecting ridge (pl. 9 , figs. 5,6 ). The resilial pit on the left valve may be bordered by a ridge that is followed by a groove and a second shorter ridge (pl. 8, fig. 5) or may be bordered by only one ridge (pl. 9, fig. 1). On one articulated specimen, the right-valve resilial ridges rested in grooves between the left-valve resilial ridges. On all specimens, the inner shell is thickened parallel to the line of attachment of the ears.

On the anterior portion of the right valve, although the shell is thickened, producing a strong smoothly rounded ridge (pl. 9, fig. 6), the ridge does not end in a denticle. On some specimens, however, the ridge ends in a slightly prominent node which on a few specimens could perhaps be considered an auricular denticle. At the posterior side of the right valve, the distal portion of the thickened shell ends in a rounded to somewhat pointed denticle (pl. 9, figs. 5, 6).

On the anterior portion of the left valve, the thickened ridge usually terminates in a rounded denticle or a somewhat triangular ridge (pl. 8, fig. 2); on some specimens, however, no auricular denticle can be distinguished. The thickened ridge on the left-valve posterior side is somewhat larger than the anterior ridge at the distal end and may terminate in a subdued denticle (pl. 6, fig. 4).

\section{MICROSCULPTURE}

Plate 5, figure 4; plate 6, figure 2; plate 10, figures $1,3-5$; plate 11 , figures 1-3; plate 12 , figures $1-3$; plate 13 , figure 5 ; plate 14 , figures 1,2 ; plate 15 , figure 1

Small patches of an imbricated microsculpture similar to that found on many different pectinids such as Vertipecten (Moore, 1963, p. 63), Chlamys ( Verrill, 1899 , p. 73), and on some, if not all, species referred to Yabepecten by Masuda (1963, pl. 22, fig. 4) are preserved on some left valves of $P$. healeyi (pl. 10, figs. 1, 3. 4); one juvenile specimen shows the entire surface to be so sculptured (pl. 10, fig. 4).

Meek (1864, p. 26-27), in describing Patinopecten propatulus (Conrad) from the Miocene of Oregon, said ***it shows, under a magnifier, a very peculiar and beautiful style of sculpture resembling somewhat the regularly disposed asperities on the surface of a rasp***.

In 1899 Verrill (p. 73-74, pl. 16, figs. 4, 5, 5a, 5b) named a new variety of Chlamys and illustrated a microsculpture similar to that on $P$. healeyi, which he described as follows:

The concentric and divergent laminae and smaller riblets cross each other in such a way that a peculiar decussated sculpture is formed between the primary ribs on the early part of the shell, while on the older parts the interspaces are covered with elevated scales.

Dall (1878, p. 14) said, in describing the upper (left) valve of Pecten expansus ( = Patinopecten healeyi):

The entire surface is covered with fine, slightly raised, sharp lamellae, which are waved in some places so regularly as to produce the appearance of a delicate reticulation, which, however, does not really exist ${ }^{* * *}$.

Waller (1972a, p. 229) used the term shagreen for a similar microsculpture that he defined as a screenlike pattern of openings between projecting lamellae on the shell exterior. On the caption for his figure 12 (p. 229 ), he described the specimen illustrated as showing uneroded areas with strongly projecting, cell-forming flanges and eroded areas forming the typical shagreen pattern.

MacNeil (1961, p. 227) noted that

No specimens of Lituyapecten yet observed show any suggestion of the imbricating microsculpture, resembling the surface of metal lath, that characterizes left valves of Chlamys, Vertipecten, Fortipecten, and some species of Patinopecten such as $P$. yessoensis, $P$. propatulus (Conrad), and $P$. ibaragiensis Masuda ***, imbricating microsculpture occurs rarely in small patches on specimens of $P$. caurinus.

A right valve from the Pliocene Koshiba Formation of Japan referred to Yabepecten tokunagai (Yokoyama) by Masuda (1963, pl. 22, fig. 4) shows an imbricated microsculpture. The right valve of the Holocene west Pacific species Patinopecten yessoensis (Jay) also shows an imbricated microsculpture (pl. 14, fig. 1). Al- 
though this microsculpture is fairly common on the left valve of east Pacific Patinopecten, it has not been found on the right valve.

One well-preserved juvenile left valve of $P$. healeyi (pl. 10, figs. 4,5 ) was found that had the imbricated microsculpture well preserved and was small enough to be mounted for the scanning electron microscope without destruction. The specimen was scanned from the dorsal to the ventral margin in the center of the disk between the same two ribs, and the progressive development of the microsculpture can be seen (p1. 11, figs. $1-3$; pl. 12, figs. 1-3). This imbricated microsculpture has been found on young portions of the left valve of $P$. healeyi but has not been seen on the mature parts of the shell. The fact that it develops on only a small portion of the shell and is fragile and easily abraded makes its preservation fortuitous. Waller (written commun., 1977) said that on some Chlamys this microsculpture can appear, disappear, and reappear more than once during ontogeny and that this uneven occurrence is primary and not the result of erosion.

On an especially well-preserved left valve from unnamed Pliocene strata on San Clemente Island, closely spaced concentric lamellae are preserved (pl. 5, fig. 3); these lamellae are seen to be parallel and not imbricated on the electron micrograph of a shell fragment broken off the ventral edge (pl. 5, fig. 4).

During examination of specimens of the Holocene species Patinopecten yessoensis (Jay), it was noted that imbricated lamellae merge to form a pseudosurface, apparently leaving a honeycomblike structure beneath. This outer layer is loosely cemented to the underlying shell, rarely preserved, and when removed by abrasion leaves a barely traceable pattern on the shell (Moore, 1963, p. 63).

Imbricated microsculpture may prove useful in determining the evolutionary trend of the Patinopecten bearing it, as it is seen only on left valves in the east Pacific but is also found on right valves of Patinopecten yessoensis and Yabepecten tokunagai (Yokoyama) in the west Pacific.

Because this paper is intended to call attention to specific variation, and I have not dealt extensively with genera other than Patinopecten, I have chosen a conservative approach and used the genus Patinopecten for species that have been assigned by others to Mizuhopecten (Masuda, 1963) but have considered Yabepecten (Masuda and Addicott, 1970) to be a valid genus. I do wish to emphasize, however, that the microsculpture on the west Pacific species of Patinopecten is different from the sculpture on the east Pacific species. It seems plausible to me that as more data are accumulated, using the scanning electron microscope, microsculpture may prove to be useful in the taxonomy of the pectinids. In the course of this study, I have found that large specimens unsuitable for mounting for the scanning electron microscope can be coated with a plastic spray, covered with a thick coat of liquid latex, the coating then removed and filled with colorless fingernail polish and the hardened polish mounted for the scanning electron microscope. This technique proved quite successful and should make it possible to study the microsculpture on specimens of any size.

\section{COMPARISON WITH OTHER SPECIES}

Patinopecten healeyi is closely similar to $P$. lohri (Hertlein) and sometimes confused with that species. Patinopecten lohri (Hertlein) (1928, p. 93) was originally described as Pecten (Patinopecten) oweni Arnold (1906, p. 63 , pl. 8 , figs. $1,1 \mathrm{a}, 1 \mathrm{~b})$, a name that was preoccupied. The holotype of $P$. lohri (pl. 13, figs. 3, 4, 6 ), according to Woodring (in Woodring and Bramlette, 1950 , p. 83-84), was presumably collected from the Tinaquaic Sandstone Member (early and middle Pliocene) of the Sisquoc Formation somewhere near Foxen Canyon, Calif. In his discussion of Patinopecten lohri from the Santa Maria basin of California, Woodring (in Woodring and Bramlette, 1950, p. 83) said that

The ribs on large left valves of $P$. lohri are wide and divided, whereas on $P$. healeyi they are narrow and not divided, or on some very large left valves are moderately wide and faintly divided by one or more shallow grooves. Right valves of $P$. lohri generally have a strong secondary rib in the space between the primary ribs, whereas on right valves of $P$. healeyi secondary ribs are absent or, if present, generally are weak. Some right valves of $P$. lohri, however, lack secondary ribs or have weak secondaries. Left valves of both species have secondaries. Owing to the presence of divided ribs on both valves of $P$. lohri, right and left valves are difficult to distinguish unless the ears are preserved, whereas right and left valves of $P$. healeyi are readily differentiated.

The right valve of the holotype (UCMP 12081) of $P$. lohri (pl. 13, figs. 3,4) is more inflated than is typical for $P$. healeyi; the primary ribs are higher, dichotomous at an earlier stage, fewer in number (14), and therefore more widely spaced. Each interspace bears a wide secondary rib that first appears when the shell has reached a height of about $30 \mathrm{~mm}$. The primary ribs are deeply dichotomous, the first division of a rib taking place when the shell is about $15 \mathrm{~mm}$ in height, the last at about $55 \mathrm{~mm}$. At the ventral margin of the holotype, which is about $90 \mathrm{~mm}$ in height, the primary ribs, except two at each of the margins of the shell, are dichotomous, and two near the posterior margin are completely divided. Both sides of the split ribs are more rounded than on $P$. healeyi. A narrow unsculptured band is present along the posterior margin of the shell. The right anterior auricle is poorly 
preserved but seems to be sculptured by subdued riblets and to have a byssal notch similar to $P$. healeyi. The posterior auricle bears a shallow groove bordered by low ridges; this feature is discernible on about two-thirds of the auricle but seems to disappear before reaching the posterior edge. The right anterior auricle is broken at the margin but was possibly not as high as the left anterior auricle. The right valve is noticeably inequilateral, and the anterior margin, excluding the auricle, forms an angle of about $40^{\circ}$ with the hinge; the posterior margin an angle of about $25^{\circ}$.

The left valve of the holotype of $P$. lohri (pl. 13, fig. 6 ) bears fewer (12) primary ribs than $P$. healeyi, and these ribs are therefore more widely spaced. The ribs are also higher, especially on the younger portion of the shell, than is typical for $P$. healeyi. Each interspace has a strong secondary rib, and three of the interspaces closest to the posterior margin bear two secondary ribs. The shell is worn, but traces of concentric lamellar sculpture similar to that seen on some specimens of $P$. healeyi are visible under magnification. A few of the primary ribs near the central portion of the shell have subdued shell protuberances that seem not to be primary structures but rather to be related to a time of breakage and subsequent repair of the shell. The left valve is strongly inequilateral, and the posterior shell margin, excluding the ear, forms an angle of $25^{\circ}$ with the hinge and with the anterior margin, $40^{\circ}$. The ears are markedly inequilateral, the posterior being about $26 \mathrm{~mm}$ long and $13 \mathrm{~mm}$ high and the anterior about $30 \mathrm{~mm}$ long and $22 \mathrm{~mm}$ high. As discussed, a similar inequilateralty is seen on large specimens of $P$. healeyi.

Arnold, in describing P. lohri (1906, p. 63) as Pecten (Patinopecten) oweni Arnold, said that it may be distinguished from $P$. healeyi by its smaller size, greater convexity, fewer and stronger ribs, more prominent intercalary riblets on the right valve, and relatively much longer hinge line.

The smooth form of $P$. healeyi is surprisingly similar in external sculpture to Yabepecten condoni (Hertlein, 1925, p. 41, pl. 4, figs. 8, 9) from the Montesano Formation (Miocene) of Washington, as figured by Masuda and Addicott (1970, figs. 1, 3-9). The rightvalve primary ribs on $P$. healeyi are typically dichotomous, whereas they are rarely so on $Y$. condoni. The left-valve sculpture of $Y$. condoni seems to consist of small fine primaries with only occasional secondaries, whereas secondaries are commonly present in the left-valve interspaces on $P$. healeyi. According to Masuda and Addicott (1970, p. 154), the hinge of $Y$. condoni has simple cardinal crura and a wide and shallow resilial pit, both characters that would separate it from $P$. healeyi.
Hertlein (1925, p. 41), in describing $Y$. condoni, said that it has about 16 smooth faint ribs that broaden rapidly as the shell grows and are about two or three times as wide as the very slight interspaces at the ventral margin. He also noted that the right valve bears concentric lines of growth that are very prominent on some specimens and almost lacking in others, that the right-valve auricles are small, and that the anterior auricle bears a very slight byssal notch. The left-valve sculpture is similar to that of the right. The slight byssal notch on the right-valve auricle and the similarity of sculpture of the right and left valves are other characters that separate $Y$. condoni from $P$. healeyi.

Lituyapecten turneri (Arnold) differs from P. healeyi by having very narrow, high, medially sulcated ribs and wide interspaces on the right valve and high narrow ribs on the left valve with no intercalaries (Arnold, 1906, p. 106, pl. 34, fig. 4; pl. 35, figs. 2, 3; Peck, 1960, pl. 21, figs. 15, 16).

Yabepecten tokunagai (Yokoyama) differs from $P$. healeyi in right-valve sculpture, having low, rounded, closely spaced ribs. In addition, an imbricated microsculpture is present on the right valve (Masuda, 1963, pl. 12, fig. 4), and this sculpture has been found only on left valves of $P$. healeyi.

The marked consistent dichotomy of the right-valve ribs separates $P$. healeyi from other Patinopecten with the exception of $P$. lohri, already discussed. Although several species such as Patinopecten oregonensis (Howe), Patinopecten coosensis (Dall), and Patinopecten oregonensis cancellosus Moore may have a few dichotomous ribs at the anterior and posterior margins of the right valve, none bear low, flat, dichotomous ribs over the entire shell surface.

\section{GEOGRAPHIC AND STRATIGRAPHIC DISTRIBUTION OF PATINOPECTEN HEALEYI (ARNOLD) AND P. LOHRI (HERTLEIN)}

Patinopecten lohri is restricted to the Pliocene of California, and Patinopecten healeyi to the Pliocene of California and Baja California. Both species first appear in the early Pliocene and, as unique split-ribbed giant pectinids, are of significance in the interpretation of Neogene zoogeography and age determination (Addicott, 1974, p. 191). The base of the Jacalitos Stage $^{1}$ is defined by the lowest occurrence of the split-ribbed species of Patinopecten, $P$. healeyi and $P$. lohri (Addicott, 1972, p. 15-16). Although most Patinopecten have one or two split ribs on the right valve, none show the unique sculpture of $P$. healeyi and $P$. lohri, which typically have all of the rightvalve primary ribs split.

${ }^{1}$ Epoch assignments used herein follow the West Coast provincial usage outlined by Weaver and others (1944). 


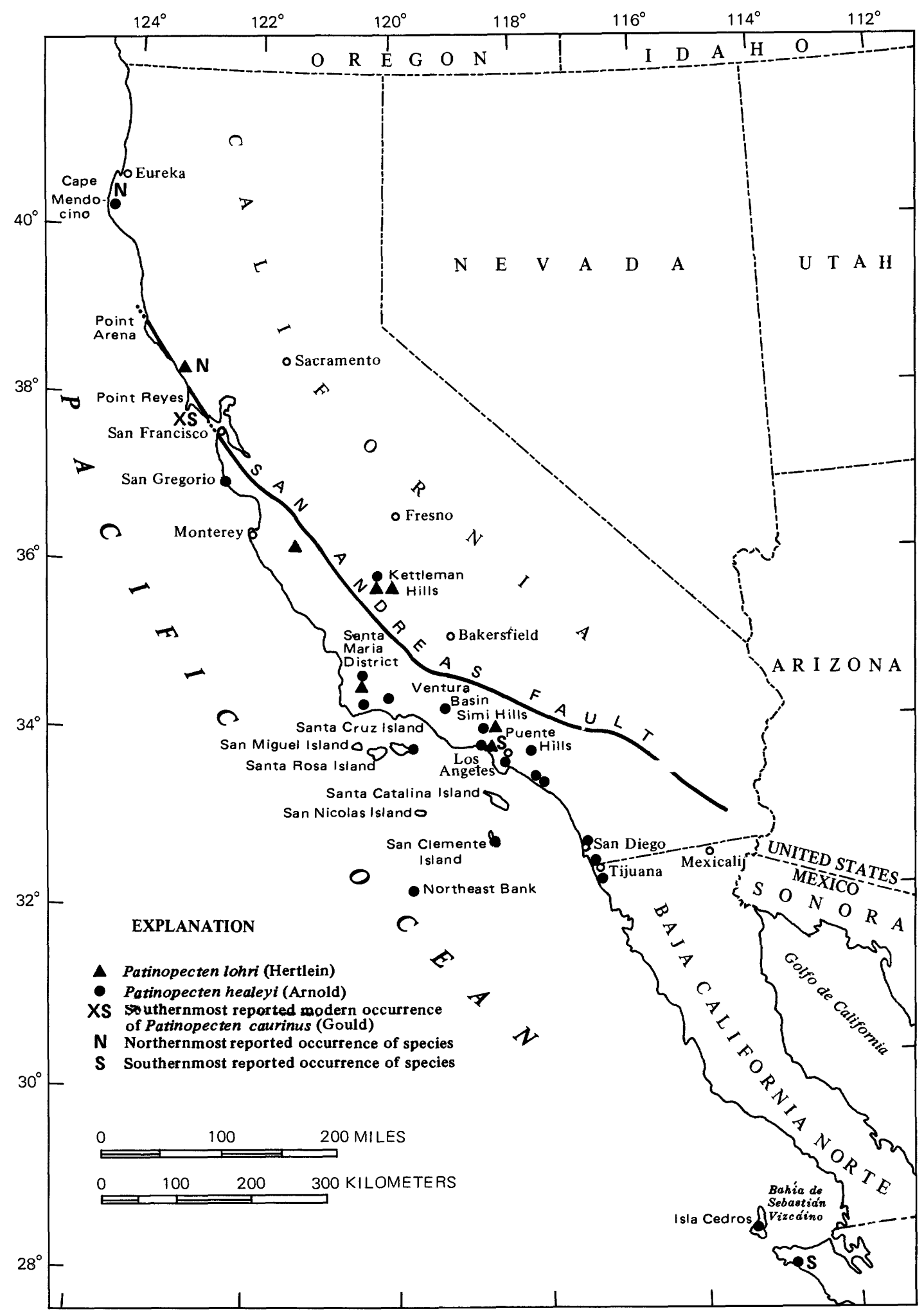

FIgURE 1.-Geographic distribution of Patinopecten healeyi (Arnold) and Patinopecten lohri (Hertlein) and southern modern occurrence of Patinopecten caurinus (Gould). (Compiled from Cummings and others, 1962; Dibblee, 1950; Durham and Addicott, 1965; Durham and Yerkes, 1964; Faustman, 1964; Glen, 1959; Hawkins and others, 1971; Hertlein and Grant, 1972; Jordan and Hertlein, 1926; Kern, 1973; Martin, 1916; Minch and others, 1976; Ogle, 1953; Stanton and Dodd, 1976; Vedder and Moore, 1976; Weaver and Meyer, 1969; Winterer and Durham, 1962; Woodring, 1930; Woodring and others, 1940; Woodring and Bramlette, 1950.) 
The northernmost occurrences of $P$. healeyi are in the Eureka and Cape Mendocino areas of northern California (Ogle, 1953, pl. 5), the northernmost of $P$. lohri in the Point Reyes area (fig. 1). Specimens from the Falor Formation (Pliocene) on the bank of Boulder Creek, Blue Lake quadrangle, were loaned to me through the kindness of J. W. Durham, University of California; these specimens are typical $P$. healeyi. A concretion containing $P$. healeyi, also loaned me by Durham, was collected from beach drift at the base of the Cliff House in San Francisco. Presumably it came from the Merced Formation (Pliocene) offshore; this formation is known on land to the south. P. lohri has been found no farther south than the Santa Maria basin northwest of Los Angeles (Woodring and Bramlette, 1950 , p. 65), whereas $P$. healeyi occurs as far south as the Vizcaino Peninsula of Baja California Sur (Jordan and Hertlein, 1926, p. 417; Minch and others, 1976, p. 176).

The two species are reported to occur geographically together at only three areas in California: the northern Santa Cruz Mountains (Cummings and others, 1962, pl. 24), the Kettleman Hills area (Stanton and Dodd, 1976, p. 91, fig. 4), and the Santa Maria basin (Woodring and Bramlette, 1950, p. 65). As will be shown, nowhere do the two species cooccur in one locality, and, in general, $P$. lohri occurs stratigraphically lower than $P$. healeyi.

Patinopecten healeyi and P. lohri are reported near each other from the same stratigraphic interval in only one area, the Jacalitos Canyon area near Kettleman Hills (Stanton and Dodd, 1976, p. 91, fig. 4). In the Santa Maria basin, $P$. lohri is found stratigraphically below $P$. healeyi, but in the Santa Cruz Mountains, it is reported to be stratigraphically above. The Santa Cruz Mountains occurrence may be in error, as the forms collected could well be a new species of Patinopecten (Clark, 1966) that closely resembles $P$. healeyi and is known to occur in the Santa Cruz Mountains. Unfortunately, the material collected by Cummings, Touring, and Brabb (1962) is missing and presumed to be lost.

Arnold (1906, p. 63) found P. lohri in the lower part of the Purisima Formation, where, he stated, $P$. lohri seems to grade into $P$. healeyi, the form occurring at Lobitas and Purisima identified as $P$. healeyi serving as the link between the two species. Arnold (1906, p. 104, pl. 37, fig. 2) illustrated a specimen of $P$. healeyi from San Gregorio in San Mateo County and said that the right-valve specimens of $P$. healeyi from this area generally have flatter, more deeply dichotomous ribs than are typical of this species and left valves with secondary ribs nearly equal in size to the primary ribs. But he noted also that similar variation occurs in specimens from San Diego County and therefore con- cluded that these differences are not of taxonomic significance. Specimens that I have collected from San Gregorio certainly all fall within the range of sculptural variation of $P$. healeyi.

The Patinopecten identified as $P$. (P.) $\mathrm{cf}$. $P$. (P.) healeyi in the Santa Margarita Formation in the Felton quadrangle of the Big Basin area in San Mateo County by Clark (1966) is here assigned to Lituyapecten purisimaensis (Arnold).

In the northern Santa Cruz Mountains, Patinopecten lohri is found in the Pomponio and San Gregorio Members of the Purisima Formation, as used by Cummings, Touring, and Brabb (1962), pl. 24), stratigraphically above the occurrence of Patinopecten healeyi in their Tahana Member of the Purisima Formation in the same area. As stated, $P$. healeyi may have been confused with $P . \mathrm{n}$. sp. Clark in this area.

Grant and Gale (1931, p. 198) said that $P$. lohri and $P$. healeyi commonly occur together but that at some places $P$. lohri is more common in older horizons. Stewart (in Woodring, Stewart, and Richards, 1940, p. 91-92) noted that the specimen from Elsmere Canyon in Ventura County figured by Grant and Gale (1931, pl. 6, figs. $1 \mathrm{a}, 1 \mathrm{~b}$ ) as $P$. lohri probably is $P$. healeyi, and I concur. Stewart identified $P$. lohri in the Etchegoin Formation of the Kettleman Hills, where he found it to be especially common in the Patinopecten Zone. Kern $(1973$, p. 13,74$)$ recorded $P$. lohri in the Towsley Formation in the San Fernando quadrangle.

Woodring (in Woodring and Bramlette, 1950, p. 83), in discussing the occurrence of Patinopecten in the Santa Maria district, said that $P$. lohri is found in the oldest formation containing marine Pliocene fossils, $P$. healeyi in the youngest, and Lituyapecten dilleri in intervening strata, and that although their ranges overlap, the three species are stratigraphically useful. $\mathrm{He}$ added that $P$. lohri is present in the Tinaquaic Sandstone Member of the Sisquoc Formation and a comparable form in diatomaceous strata of the Sisquoc; a variety of $L$. dilleri in diatomaceous strata of the Sisquoc and $L$. dilleri proper in the Foxen Mudstone and the Cebada Member of the Careaga Sandstone; and $P$. healeyi in the Foxen Mudstone and the Careaga. $P$. healeyi and $P$. lohri do not occur within the same stratigraphic interval in the Santa Maria district, although both are associated with $L$. dilleri.

Stanton and Dodd (1976, p. 90-91) noted that $P$. lohri is more common in the upper part of the Jacalitos Formation of former usage, as it was originally mapped in the Zapato Chino section of the Jacalitos Canyon area, and that the fauna contained in this section is strongly suggestive of zones low in the Etchegoin Formation as exposed in North Dome in the Kettleman Hills. They collected $P$. lohri from the 
middle upper part of the so-called Jacalitos and the upper middle part of the San Joaquin Formations and $P$. healeyi from the middle part of the San Joaquin Formation. In the Jacalitos Canyon sections then $P$. healeyi and $P$. lohri occur within the same stratigraphic interval; even there, they were not collected together at the same locality (Stanton and Dodd, 1976, p. 91, fig. 4).

Patinopecten lohri has not been found in the Niguel, Fernando, or San Diego Formations in southern California, where $P$. healeyi is commonly collected, presumably because these areas are beyond the southernmost range of $P$. lohri.

It is apparent that part of the stratigraphic range of $P$. healeyi and $P$. lohri, as well as part of the geographic range, is the same. Yet the two species seem never to have been collected together from one locality despite reports to the contrary. P. lohri is more common in middle California, $P$. healeyi more common in southern California; $P$. lohri is less common generally and much more restricted in its geographic occurrence. Of a total of approximately 135 species of mollusks that occur with $P$. lohri (Durham and Addicott, 1965, table 1, p. A12-A14), about 40 species are not found with $P$. healeyi, although the same genera occur with both species. The reported stratigraphic occurrence of the two species, assuming all identifications to be correct, precludes the possibility sometimes suggested that $P$. healeyi was the descendant of $P$. lohri (Arnold, 1906, p. 63; Hertlein, in Hertlein and Grant, 1972, p. 185). Perhaps the explanation for the distribution of $P$. healeyi and $P$. lohri lies in ecologic parameters not yet apparent from the fossil record.

\section{ECOLOGY}

On the basis of what we know about the living habits of modern pectinids, especially Patinopecten, some speculations can be made on the ecology of $P$. healeyi.

Fitch (1953, p. 44) stated that the geographic range of the modern Patinopecten caurinus (Gould) is from Wrangell, Alaska, to Eureka, Calif., and that the species is frequently taken in considerable numbers by flatfish trawlers at depths of 58 to $88 \mathrm{~m}$. Grau (1959 p. 147-148) gave the geographic range of $P$. caurinus as Channel Inlet, Orca Inlet, Cordoba, Alaska, to Point Reyes, Calif., the bathymetric range as 37 to $183 \mathrm{~m}$, or possibly deeper. F. R. Bernard (written commun., 1976) says that $P$. caurinus lives at depths of 15 to $275 \mathrm{~m}$ and that in British Columbia its maximum population density occurs at about $35 \mathrm{~m}$ on a mixed sand and mud bottom. In the natural habitat, the species has been observed lying in small depressions that are presumed to be a result of current scour around the shell.

$P$. caurinus, off British Columbia, is not an active swimmer (F. R. Bernard, written commun., 1976). It remains in the same place and moves only when directly threatened by contact with a starfish. The typical pattern of movement consists of vigorous valvepumping, moving the animal upward at an angle of about $45^{\circ}$ for 2 meters or so, then a cessation of activity and fall through the water. At all times, the right valve is downmost. Although all individuals move, the smaller of the nonsessile animals are more active.

$P$. caurinus is bysally attached to a size of about 3 to $4 \mathrm{~cm}$ in shell diameter (F. R. Bernard, written commun., 1976) and has a ctenolium during its young stage.

The predators of $P$. caurinus are Octopus and the large sun-star Pycnopodia; juveniles are attacked by crabs (F. R. Bernard, written commun., 1976). Fleming (1957, p. 14) noted that fossil pectinids under 30 $\mathrm{mm}$ long are much rarer than large individuals and believes that predatory benthic fish probably eat more young pectinids than adults.

Waller (1972b, p. 55) suggested that radial ribs of pectinid shells serve to buttress the thin growing edges of the shells against crushing forces exerted by predators and to stabilize the living position in shifting sediment. As noted earlier, the right valve of $P$. healeyi, presumed to be the lower, may extend beyond the left valve by as much as $10 \mathrm{~mm}$. This extension may help keep silt from being washed up onto the soft parts of the animal when it is at rest with the valves open. It may also produce a closure less accessible to the possible predators of $P$. healeyi, such as Octopus and Pycnopodia, for rather than being able to approach the interlocked margin of both valves, it would be necessary for them to pry up the left valve or break off the extension of the right valve. Specimens of $P$. healeyi in the collections show repeated breakage and subsequent repair to the shell (pl. 1, fig. 8; pl. 7, fig. 1 ; pl. 8 , figs. 3,6 ), and this breakage is more common on the left valve. Many shells also show nonrepaired breakage and chipping at the margins, but this damage could have occurred after the animal died.

Cahn $(1951$, p. 56) noted that Patinopecten yessoensis (Jay) has the following growth rate:

1 year: $3.0 \mathrm{~cm}$.

2 years: $7.0 \mathrm{~cm}$

3 years: $10.3 \mathrm{~cm}$

4 years: $13.0 \mathrm{~cm}$

5 years: $14.8 \mathrm{~cm}$

Masuda (1962, p. 213) reported that the shells of Patinopecten yessoensis (Jay) of Japan are rather large in size in calm seas and that the convexity of the right 
valve is low and the left valve rather inflated, whereas those living in less calm water have thick shells with a more convex right valve and a nearly flat left valve.

Waller (1973, p. 46) collected thin specimens of $A r$ gopecten gibbus (Linné) in Harrington Sound, Bermuda, that he felt were within the range of variation of that form. He thought that these specimens might be the offspring of shallow-water populations that had entered the Subthermocline Zone as larvae, where there was little mixing of water, resulting in cooler, oxygen-poor water (Waller, 1973, p. 35). Subsequent growth might then have been modified by the conditions present in the subthermocline environment. Clark $(1976$, p. 607,610$)$ found that the convexity of the shell of Argopecten gibbus, in Harrington Sound, Bermuda, changed with depth from markedly convex in shallow water $(7 \mathrm{~m})$ to only slightly convex in deeper water $(21 \mathrm{~m})$ and concluded that turbulence was most likely to be the environmental variable affecting shell convexity. It is possible that the smooth form of $P$. healeyi is a response to some such unusual ecologic condition.

Rowland (1972, p. 27) noted that the fauna in the San Diego Formation exposed at Pacific Beach indicates a sand-cobble open coast environment, whereas the fauna in the San Diego Formation exposed on the San Diego Mesa, about $10 \mathrm{~km}$ to the northwest, represents quiet water. It has been suggested that the San Diego Formation exposed at Pacific Beach and the San Diego Formation exposed in the San Diego Mesa may represent different times of deposition (Woodring and Bramlette, 1950, p. 104-107; Rowland, 1972, p. 27). Recent geologic mapping in San Diego County (M. P. Kennedy in Kennedy and Peterson, 1975, p. 29, 49-50) has shown, however, that these two areas are not significantly different in age. The fauna that occurs in the San Diego Formation in northwestern Baja California, near Tijuana, Mexico, is believed to represent three environments: littoral-sublittoral rocky coast, sublittoral open coast with sand substrate, and sublittoral open coast with fine mud or mud-sand substrate (Rowland, 1972, p. 27-28). P. healeyi is found at all these localities in all of these proposed environments but may have been transported into certain environments, such as the rocky coast, rather than have lived in them.

Patinopecten healeyi most likely lived at a depth of 15 to $275 \mathrm{~m}$, perhaps with its greatest concentration around 35 to $85 \mathrm{~m}$, depending on the water temperature, as the greatest density of $P$. caurinus is around $35 \mathrm{~m}$ in British Columbia (F. R. Bernard, written commun., 1976) and between 55 and $85 \mathrm{~m}$ in more southern waters (Fitch, 1953, p. 44). During the Pleis- tocene, $P$. caurinus lived as far south as San Pedro in the Los Angeles area (Arnold, 1903, p. 37, 107); the southernmost modern occurrence of $P$. caurinus is Point Reyes, Calif., north of the known Pliocene distribution of $P$. lohri and $P$. healeyi; this suggests that $P$. caurinus may prefer cooler water than did its possible predecessors. The Pliocene mollusks and other invertebrates that occur with $P$. healeyi indicate shallow water, intertidal to $50 \mathrm{~m}$.

Patinopecten healeyi was presumably attached by a byssus when young. Mature individuals probably could swim in the sense that they could make a dart up off the bottom and then resettle when directly threatened by their predators, which may have been Octopus and starfish.

\section{CONCLUSION}

It is my opinion that the different sculptural forms of $P$. healeyi may represent responses to the environment. The sculptural variation within single lots of specimens from the same locality shows that the variation is not of stratigraphic significance.

Imbricated microsculpture found on the left valve of $P$. healeyi occurs only on the left valves of other Patinopecten in the east Pacific. In the west Pacific, this microsculpture is found on both the right and left valves of pectinids assigned to the genera Mizuhopecten and Yabepecten by other workers. Use of the scanning electron microscope in the study of microsculpture may prove useful in the separation of genera or subgenera of pectinids and in the study of the evolution of the group.

\section{FOSSIL LOCALITIES (PLIOCENE, CALIFORNIA)}

U.S. Geological Survey:

M2096: San Juan Capistrano 7.5-minute quadrangle (1949 ed.). Between Aliso Creek and U.S. Highway 101 in gully wall about $4.8 \mathrm{~km}$ south of El Toro town; $235 \mathrm{~m}$ south and $45 \mathrm{~m}$ east of NW cor. sec. 11, T. 7 S., R. 8 W., altitude about $120 \mathrm{~m}$. Niguel Formation. J. G. Vedder, 1953 and 1962.

M2098: San Juan Capistrano 7.5-minute quadrangle (1949 ed.). About $4.8 \mathrm{~km}$ south of San Juan Capistrano; $505 \mathrm{~m}$ south and $775 \mathrm{~m}$ west of NW cor. sec. 24 , T. 7 S., R. 8 W., altitude about $105 \mathrm{~m}$. Niguel Formation. J. G. Vedder, 1954.

M2753: Newport Beach 7.5-minute quadrangle. Approximately $785 \mathrm{~m}$ southeast and $775 \mathrm{~m}$ southwest of north corner Irvine Block 52. Altitude about $30 \mathrm{~m}$. In artificial cut near top of bluff overlooking upper Newport Bay. Fernando Formation. J. G. Vedder, 1966.

M3627: La Jolla 7.5-minute quadrangle. North end of Pacific Beach, collected from north end of pumping station off Wilbur Street to a point about $60 \mathrm{~m}$ north. San Diego Formation. J. G. Vedder, 1961.

M3628: La Jolla 7.5-minute quadrangle. South end of Pacific Beach, off Law Street, slightly south of dead end. San Diego Formation. J. G. Vedder, 1961. 
M5040: Newport Beach 7.5-minute quadrangle, Orange County. Approximately $900 \mathrm{~m}$ northeast and $775 \mathrm{~m}$ northwest of south corner Irvine Block 52 in new cut trending $\mathrm{N}$. $84^{\circ}$ E. Altitude about $10 \mathrm{~m}$. Fernando Formation. J. G. Vedder, 1972.

M6502: San Clemente Island. $610 \mathrm{~m}$ east and $135 \mathrm{~m}$ north of BM 554, San Clemente Island North 7.5-minute quadrangle (1950 ed.). Altitude approximately $50 \mathrm{~m}$ in resistant limy outcrop high on east side of steep gully draining northeast side of island. Unnamed Pliocene rocks. J. G. Vedder, 1975.

M6503: San Clemente Island. $615 \mathrm{~m}$ east and $25 \mathrm{~m}$ north of BM 553, San Clemente North 7.5-minute quadrangle (1950 ed.). Altitude approximately $70 \mathrm{~m}$ in new road cut not shown on map, about $160 \mathrm{~m}$ southwest of lighthouse on seacliff $4,020 \mathrm{~m}$ southeast of Wilson Cove. Unnamed Pliocene rocks. J. G. Vedder, 1975.

California Academy of Sciences:

CAS 105: Sea cliffs at Pacific Beach, La Jolla 7.5-minute quadrangle. San Diego Formation.

Natural History Museum Los Angeles:

LAM 107: Quarry at end of Arroyo Drive, known locally as Clay Canyon or Clay Quarry. San Diego Formation. G. P. Kanakoff

LAM 122: Pacific Beach, La Jolla 7.5-minute quadrangle. Exposure at shore bluff at bend at end of Loring Street. San Diego Formation. G. P. Kanakoff.

LAM 305: North of Mexican border, San Ysidro 7.5-minute quadrangle. From $30 \mathrm{~m}$ of exposure, 1.5 to $4 \mathrm{~m}$ thick, exactly $530 \mathrm{~m}$ from Mexican border fence. "K" Ranch, Palm City. San Diego Formation. G. P. Kanakoff.

LAM 305A: West side of next gully east of LAM 305, same elevation. G. P. Kanakoff.

LAM 485: National City 7.5-minute quadrangle (1953 ed.). From $6 \mathrm{~m}$ thick, mostly unconsolidated, yellow, medium- to coarse-grained sandstone on $30^{\circ}$ bulldozed slope at locality north of Market Street and east of Euclid Avenue. Projected intersection of arrows on edges of NW $1 / 4$ of map marked "2.6 mi. to U.S. 101 " and "0.6 mi. to U.S. 80 " mark this locality. San Diego Formation. E. C. Wilson, 1967.

LAM 4902: Pacific Beach, La Jolla 7.5-minute quadrangle. South-facing exposure on north side of lot on northeast corner of Edgeworth Road and Belloc Court. Collected from a yellow-tan fine- to medium-grained sandstone, unindurated, 1 to $3 \mathrm{~m}$ up bank. San Diego Formation. G. L. Kennedy, 1965, 1966.

LAM 5108: A general locality number for LAM localities 20, $107,108,122$, and 180 , which were mixed, but all from San Diego Formation.

Stanford University: SU 1605. Rikuoku (Japan).

\section{REFERENCES CITED}

Addicott, W. O., 1972, Provincial middle and late Tertiary molluscan stages, Temblor Range, California, in Symposium on Miocene biostratigraphy of California: Soc. Econ. Paleontologists and Mineralogists, Pacific Sec., Bakersfield, Calif., March 1972, p. 1-26, pls. 1-4.

1974, Giant pectinids of the eastern north Pacific marginSignificance in Neogene zoogeography and chronostratigraphy: Jour. Paleontology, v. 48, no. 1, p. 180-194.

Arnold, Ralph, 1903, The paleontology and stratigraphy of the marine Pliocene and Pleistocene of San Pedro, California: California Acad. Sci. Mem., v. 3, 419 p., 37 pls.

- 1906, The Tertiary and Quarternary pectens of California:
U.S. Geol. Survey Prof. Paper 47, 264 p., 53 pls., 2 figs.

Cahn, A. R., 1951, Clam culture in Japan: Supreme Commander for the Allied Powers, General Headquarters, Tokyo, Nat. Resources Sec. Rept. 146, 103 p., 38 figs., 13 tables.

Clark, G. R., 2d, 1976, Shell convexity in Argopecten gibbusvariation with depth in Harrington Sound, Bermuda: Bull. Marine Sci., v. 26, no. 4, p. 605-610, 3 figs.

Clark, J. C., 1966, Tertiary stratigraphy of the Felton-Santa Cruz area, Santa Cruz Mountains, California: Stanford Univ., Stanford, Calif., Ph.D. thesis, $184 \mathrm{p}$.

Cummings, J. C., Touring, R. M., and Brabb, E. E., 1962, Geology of the northern Santa Cruz Mountains, California, in Bowen, O. E., ed., Geologic guide to the gas and oil fields of northern California: California Div. Mines and Geology Bull. 181, p. 179222, 21 photos, pls. 20-24, 4 figs., 1 table.

Dall, W. H., 1878, Fossil mollusks from later Tertiaries of California: U.S. Natl. Mus. Proc., v. 1, p. 10-16 [1879]. 1898, Contributions to the Tertiary fauna of Florida, with especial reference to the Miocene silex beds of Tampa and the Pliocene beds of the Caloosahatchie River: Wagner Free Inst. Sci. Trans., v. 3, pt. 4, p. 571-947, pls. 23-35.

Dibblee, T. W., Jr., 1950, Geology of southwestern Santa Barbara County, California, Point Arguello, Lompoc, Point Conception, Los Olivos, and Gaviota Quadrangles: California Div. Mines Bull. 150, 95 p., 17 pls., 6 figs.

Durham, D. L., and Addicott, W. O., 1965, Pancho Rico Formation, Salinas Valley, California: U.S. Geol. Survey Prof. Paper 524-A, 22 p., 5 pls.

Durham, D. L., and Yerkes, R. F., 1964, Geology and oil resources of the eastern Puente Hills area, southern California: U.S. Geol. Survey Prof. Paper 420-B, p. B1-B62.

Faustman, W. F., 1964, Paleontology of the Wildcat Group at Scotia and Centerville Beach, California: California Univ. Pubs. Geol. Sci., v. 41 , no. 2 , p. $97-160,3$ pls., 7 figs.

Fitch, J. E., 1953, Common marine bivalves of California: California Dept. Fish and Game Fish Bull. 90, 102 p., 63 figs.

Fleming, C. A., 1957, The genus Pecten in New Zealand: New Zealand Geol. Survey Paleontology Bull. 26, 69 p., 15 pls.

Glen, William, 1959, Pliocene and lower Pleistocene of the western part of the San Francisco Peninsula: California Univ. Pubs. Geol. Sci., v. 36, no. 2, p. 147-198, pls. 15-17, 5 text figs.

Grant, U. S., 4th, and Gale, H. R., 1931, Catalogue of the marine Pliocene and Pleistocene Mollusca of California and adjacent regions: San Diego Soc. Nat. History Mem., v. 1, 1036 p., 32 pls., 15 figs., 3 tables.

Grau, Gilbert, 1959, Pectinidae of the eastern Pacific: Los Angeles, Univ. Southern California, Allan Hancock Pacific Exped., v. 23, 308 p., 57 pls.

Hawkins, J. W., Allison, E. C., and MacDougall, Doug, 1971, Volcanic petrology and geologic history of Northeast Bank, southern California borderland: Geol. Soc. America Bull., v. 82, no. 1, p. 219-228, 4 figs.

Hertlein, L. G., 1925, New species of marine fossil mollusca from western North America: Southern California Acad. Sci. Bull., v. 24 , pt. 2 , p. $39-46$, pls. 3,4

1928, Pecten (Patinopecten) lohri, new name for Pecten oweni Arnold, a Pliocene species from California: The Nautilus, v. 41, no. 3 , p. 93-94.

Hertlein, L. G., and Grant, U.S., IV, 1972, The geology and paleontology of the marine Pliocene of San Diego, California (Paleontology: Pelecypoda): San Diego Soc. Nat. History Mem. 2, pt. 2b, p. $143-409,57 \mathrm{pls}$.

Jordan, E. K., and Hertlein, L. G., 1926, Contributions to the geology and paleontology of the Tertiary of Cedros Island and adja- 
cent parts of Lower California, in Expedition to the Revillagigedo Islands, Mexico, 1925: California Acad. Sci. Proc., ser. 4 , v. 15 , no. 14 , p. $409-464$.

Kennedy, M. P., and Peterson, G. L., 1975, Geology of the San Diego metropolitan area, California: California Div. Mines and Geology Bull. 200, 56 p., 6 pls., 8 photos, 12 figs., 3 tables.

Kern, J. P., 1973, Early Pliocene marine climate and environment of the eastern Ventura Basin, southern California: California Univ. Pubs. Geol. Sci., v. 96, 117 p., 27 figs., 10 tables.

MacNeil, F. S., 1961, Lituyapecten (new subgenus of Patinopecten) from Alaska and California: U.S. Geol. Survey Prof. Paper 354-J, p. 225-239, pls. 35-46 [1962].

Martin, Bruce, 1916, Pliocene of middle and northern California: California Univ. Pub. Geol. Sci. Bull., v. 9, no. 15, p. 215-259.

Masuda, Koichiro, 1962, Tertiary Pectinidae of Japan: Tohoku Univ. Sci. Repts., ser. Geology, v. 33 , no. 2, p. 117-238, pls. $18-27$.

-1963, The so-called Patinopecten of Japan: Palaeont. Soc. Japan Trans. and Proc., n.s., no. 52, p. 145-153, pls. 22, 23.

Masuda, Koichiro, and Addicott, W. O., 1970, On Pecten (Amusium) condoni Hertlein from the west coast of North America: The Veliger, v. 13, no. 2, p. 153-156, figs. 1-9.

Meek, F. B., 1864, Check list of the invertebrate fossils of North America: Smithsonian Misc. Colln. 183, 32 p.

Minch, J. C., Gastil, Gordon, Fink, William, Robinson, John, and James, A. H., 1976, Geology of the Vizcaino Peninsula, in Howell, D. G., Aspects of the geologic history of the California continental borderland: Am. Assoc. Petroleum Geologists, Pacific Sec., Misc. Pub. 24, p. 136-195, 5 figs., 17 tables.

Moore, E. J., 1963, Miocene marine mollusks from the Astoria Formation in Oregon: U.S. Geol. Survey Prof. Paper 419, 109 p., 33 pls., 9 figs., 3 tables [1964].

Ogle, B. A., 1953, Geology of Eel River Valley area, Humboldt County, California: California Div. Mines Bull. 164, 128 p.

Peck, J. H., Jr., 1960, Paleontology and correlation of the Ohlson Ranch Formation: California Univ. Pubs. Geol. Sci., v. 36, no. 4, p. $233-242$, pl. 21.

Rowland, R. W., 1972, Paleontology and paleoecology of the San Diego Formation in northwestern Baja California: San Diego Soc. Nat. History Trans., v. 17, no. 3, p. 25-32, 2 figs., 2 tables.

Stanton, R. J., Jr., and Dodd, J. R., 1976, Pliocene biostratigraphy and depositional environment of the Jacalitos Canyon area, California, in Fritsche, A. E., Best, H. T., Jr., and Wornardt, W. W., The Neogene Symposium: Soc. Econ. Paleontologists and Mineralogists Pacific Sec., Ann. Mtg., p. 85-94, 5 figs., 2 tables.
Suzuki, Takeo, and Stadum, C. J., 1978, A Neogene section, northeastern San Clemente Island, California: Los Angeles County Mus. Nat. History Contr. Sci. 299, 24 p., 29 figs.

Vedder, J. G., and Moore, E. J., 1976, Paleoenvironmental implications of fossiliferous Miocene and Pliocene strata on San Clemente Island, California, in Howell, D. G., Aspects of the geologic history of the California continental borderland: Am. Assoc. Petroleum Geologists, Pacific Sec., Misc. Pub. 24, p. 107-127, 4 pls., 1 table, 9 figs.

Verrill, A. E., 1899, A study of the family Pectinidae with a revision of the genera and subgenera: Connecticut Acad. Arts and Sci. Trans., v. 10, pt. 1, p. 41-95, pls. 16-21.

Waller, R. R., 1969, The evolution of the Argopecten gibbus Stock (Mollusca: Bivalvia), with emphasis on the Tertiary and Quaternary species of eastern North America: Jour. Paleontology, v. 43 , suppl. to no. 5,125 p., 8 pls.

1972a, the Pectinidae (Mollusca: Bivalvia) of Eniwetok Atoll, Marshall Islands: The Veliger, v. 14, no. 3, p. 221-264, 8 pls., 22 text figs.

1972b, Functional significance of some shell microsculptures in the Pectinacea (Mollusca: Bivalvia): Internat. Geol. Cong., 24th, Montreal, Canada, 1972, sec. 7, Paleontology, p. 48-56, 3 figs., 1 table.

1973, The habits and habitats of some Bermudian marine mollusks: The Nautilus, v. 87 , no. 2 , p. $31-52,2$ pls., 2 text figs.

Weaver, C. E., chm., and others, 1944, Correlation of the marine Cenozoic formations of western North America: Geol. Soc. America Bull., v. 55, no. 5, p. 569-598.

Weaver, D. W., and Meyer, G. L., 1969, Stratigraphy of northeastern Santa Cruz Island, in Weaver, D. W., and others, Geology of the northern Channel Islands: [Calif.] Am. Assoc. Petroleum Geologists and Soc. Econ. Paleontologists and Mineralogists, Pacific Secs., Spec. Pub., p. 95-104.

Winterer, E. L., and Durham, D. L., 1962, Geology of southeastern Ventura Basin, Los Angeles County, California: U.S. Geol. Survey Prof. Paper 334-H, p. 275-366, pls. 44-49, figs. 49-68, 11 tables.

Woodring, W. P., 1930, Pliocene deposits north of Simi Valley, California: California Acad. Sci. Proc., ser. 4, v. 19, no. 6, p. 57-64.

Woodring, W. P., and Bramlette, M. N., 1950, Geology and paleontology of the Santa Maria district, California: U.S. Geol. Survey Prof. Paper 222, 185 p., 23 pls., 9 figs. [1951].

Woodring, W. P., Stewart, R. E., and Richards, R. W., 1940, Geology of the Kettleman Hills oil field, California: U.S. Geol. Survey Prof. Paper 195, 170 p., 57 pls., 15 figs. 



\section{INDEX}

[Italic page numbers indicate major references]

Page

Acknowledgments
Amusium
Argopecten gibbus
Auricles

Baja California

Big Basin, California

Boulder Creek, California

Byssus

cancellosus, Patinopecten oregonensis

Cape Mendocino, California

Careaga Sandstone

caurinus, Patinopecten

Cebada Member

Channel Inlet, Alaska ...

Chlamys

Conclusion

condoni, Yabepecten

coosensis, Patinopecten

Cordoba, Alaska

Ctenolium

Dall, W. H., quoted

dilleri, Lituyapecten

Ecology

Etchegoin Formation

Eureka, California _ _-

expansus, Pecten

Pecten (Patinopecten)

1,5

Falor Formation

Fernando Formation

Fossil localities

Foxen Canyon, California

Foxen Mudstone

$1,3,10,11$

Geographic distribution

gıbbus, Argopecten

Harrington Sound, Bermuda

healeyi, Pecten (Patinopecten)

sanclementensis, Patinopecten

Pecten (Patinopecten)

Hinge area

Introduction

Jacalitos Canyon, California

Jacalitos Formation

Jacalitos Stage

Kettleman Hills, California

Koshiba Formation

La Jolla area, California

Left valve

Lituyapecten dilleri

purisimaensis$$
\text { turnert }
$$

lohri, Patinopecten

$--$

MacNeil, F. S., quoted

Meek, F. B., quoted

Merced Formation

Microsculpture

Mizuhopecten

Montesano Formation

National City, California

Newport Beach, California

Niguel Formation

North Dome, California

Octopus
Orca Inlet, Alaska

oregonensis, Patinopecten

cancellosus, Patinopecte

oweni, Pecten (Patinopecten)

Page

10

7

Pacific Beach, California

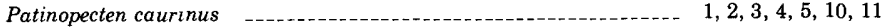

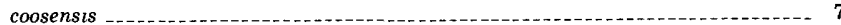

healeyı sanclementensis -... 1

lohri _.

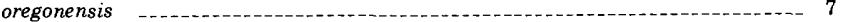
cancellosus _._. propatulus …

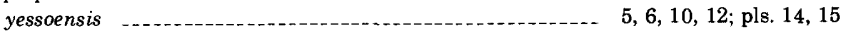

(Patinopecten) expansus, Pecten _... healeyl, Pecten sanclementensis, Pecten
saley, Pecten oweni, Pecten _.......... 6, 7

Pecten expansus _........... 1, 2, 5

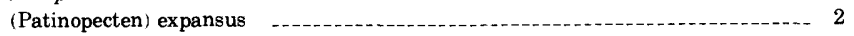
healeyi -

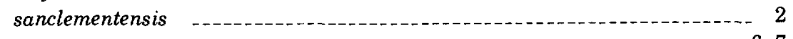

owenl

Point Reyes, California

Pomponio member -

Primary sculpture

Propatulus, Patinopecten _................. 5

Purisima Formation _........ 9

purisimaensis, Lituyapecten

Purpose

Pycnopodia -....... 10

References cited _............ 12

Right valve -........ 2

Rikuoka, Japan _............ 12

San Clemente Island, California $\ldots \ldots \ldots \ldots \ldots \ldots \ldots \ldots . . \ldots 1,2,3,4,11,12$ sanclementensis, Patinopecten healeyi

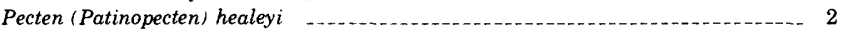

San Diego Formation $\ldots \ldots \ldots \ldots . \ldots 1,2,3,10,11,12$

San Diego Mesa _.-.--_.

San Gregorio, California

San Gregorio Member

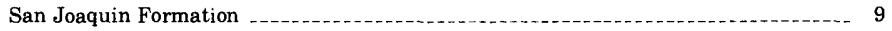

San Juan Capistrano, California

San Ysidro, California _.

Santa Cruz Mountains

Santa Margarita Formation _................ 9

Santa Maria basin ......... 3,6, 9

Scope -............... 1

Sisquoc Formation

Species comparison

starfish _ 11

Stratigraphic distribution

Tahana Member _....... 9

Tinaquaic Sandstone Member ..... 6, 9

tokunagal, Yabepecten

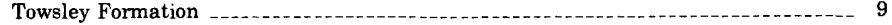

turneri, Lituyapecten

Patinopecten

Verrill, A. E., quoted _

Vertipecten .

Vizcaino Peninsula, Baja California

Waller, R. R., quoted _

Woodring, W. P., quoted

Wrangell, Alaska

Yabepecten ........ 5, 6, 11

condoni

tokunagai _........................... 5, 6, 7

yessoensis, Patmopecten

Zapato Chino section 


\section{PLATES $1-15$}

Contact photographs of the plates in this report are available, at cost, from U.S.

Geological Survey Library, Federal Center, Denver, Colorado 80225 


\section{PLATE 1}

Figures 1-8. Patinopecten healeyi (Arnold), San Diego Formation, San Diego, Calif.

1. Exterior or right valve showing typical dichotomy of primary ribs. $95 \mathrm{~mm}$ high; $98 \mathrm{~mm}$ wide; hinge $45.5 \mathrm{~mm}$ long. LAM loc. 5108. LAM 5219.

2. Exterior of right valve showing complete dichotomy of rib on anterior portion of shell. $31 \mathrm{~mm}$ high; $30 \mathrm{~mm}$ wide; hinge $16 \mathrm{~mm}$ long. LAM loc. 485. LAM $5220, \times 2$.

3. Exterior of incomplete right valve showing complete dichotomy of ribs on anterior portion of shell and riblets on posterior ear. $39 \mathrm{~mm}$ wide; hinge $17.5 \mathrm{~mm}$ long. LAM loc. 107. LAM 5221, $\times 1.50$.

4. Exterior of juvenile right valve showing smooth disk and low rounded ribs. $13.2 \mathrm{~mm}$ high; $13.0 \mathrm{~mm}$ wide; hinge $7.8 \mathrm{~mm}$ long, LAM loc. 4902 . LAM $5222, \times 3$.

5. Interior of juvenile right valve showing hinge area and ctenolium. (Same specimen illustrated as fig. 4.)

6. Exterior of right-valve fragment showing smooth disk, low rounded ribs, and ctenolium. Hinge $10.5 \mathrm{~mm}$ long. LAM loc. 107. LAM 5223, $\times 3$.

7. Exterior of right valve showing smooth disk, complete dichotomy of ribs at both anterior and posterior margins, and fine striations on posterior ear. $25 \mathrm{~mm}$ high; $24 \mathrm{~mm}$ wide; hinge $12.5 \mathrm{~mm}$ long. LAM loc. 107. LAM $5224, \times 3$.

8. Exterior of right valve showing wide unsculptured band at both anterior and posterior margins and dichotomy of all primary ribs. $153 \mathrm{~mm}$ high; $165 \mathrm{~mm}$ wide; hinge $85 \mathrm{~mm}$ long. LAM loc. 107. LAM 5225, $\times 0.60$. 

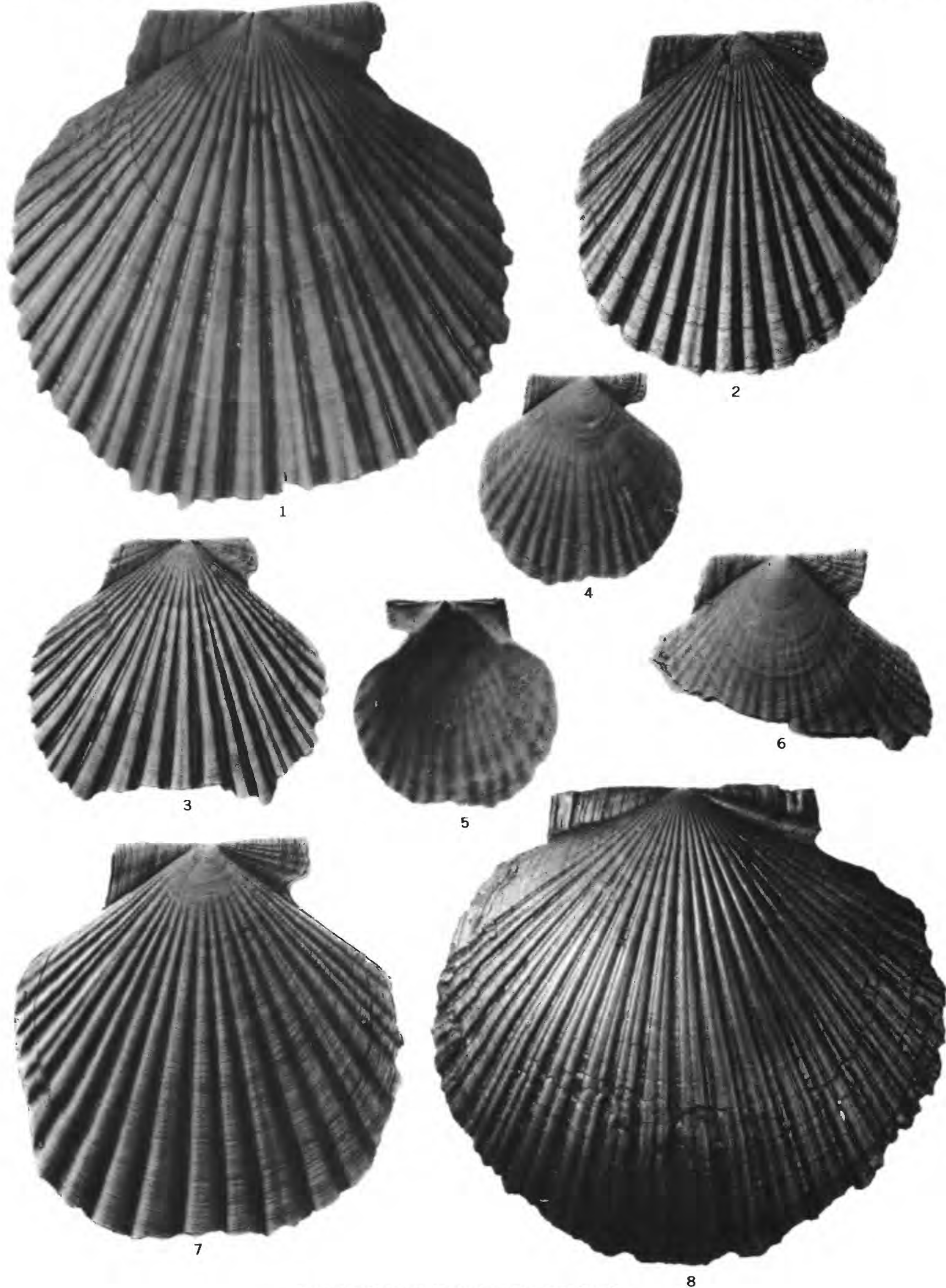

PATINOPECTEN HEALEYI (ARNOLD)

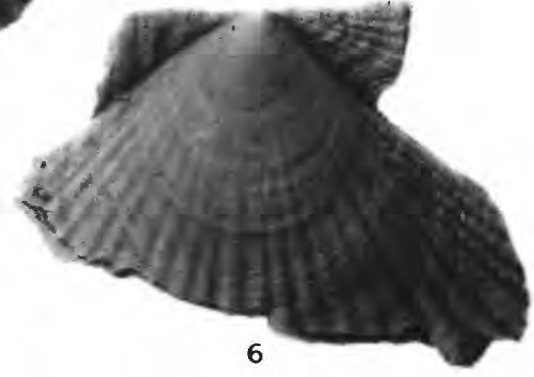




\section{PLATE 2}

Figures 1-7. Patinopecten healeyi (Arnold).

1. Exterior of right valve of intermediate form showing smooth umbo and low subdued ribs. San Diego Formation, San Diego, Calif. $75 \mathrm{~mm}$ high; 80 $\mathrm{mm}$ wide; hinge $36.5 \mathrm{~mm}$ long. CAS loc. 105. CAS 58250.

2. Exterior of right valve of intermediate form showing smooth rounded ribs over midportion of shell and dichotomous ribs at posterior margin and one near anterior margin. San Diego Formation, San Diego, Calif. 78 $\mathrm{mm}$ high; $81 \mathrm{~mm}$ wide; hinge $35.5 \mathrm{~mm}$ long. CAS loc. 105. CAS 58251.

3. Fragment of right valve of smooth form showing large smooth disk succeeded by dichotomous but very closely spaced primary ribs. Unnamed Pliocene strata, San Clemente Island, Calif. USGS M6502. USNM 235594. (Illustrated by Vedder and Moore, 1976, pl. 3, fig. 6.)

4. Exterior of juvenile left valve, presumed to be of smooth form. Unnamed Pliocene strata, San Clemente Island, Calif. $15 \mathrm{~mm}$ long; $16 \mathrm{~mm}$ high; hinge $8.7 \mathrm{~mm}$ long. USGS M6503. USNM 235590, $\times 2$. (Illustrated by Vedder and Moore, 1976, pl. 3, fig. 2.)

5. Fragment of right valve of smooth form showing dichotomous but very closely spaced ribs. Unnamed Pliocene strata, San Clemente Island, Calif. USGS M6503. USNM 235595. (Illustrated by Vedder and Moore, 1976, pl. 3, fig. 8.)

6. Exterior of small right valve of smooth form showing faint trace of subdued rib sculpture. Unnamed Pliocene strata, San Clemente Island, Calif. $50 \mathrm{~mm}$ high; $50 \mathrm{~mm}$ wide; hinge $23 \mathrm{~mm}$ long. USGS M6503. USNM 235592. (Illustrated by Vedder and Moore, 1976, pl. 3, fig. 4.)

7. Exterior of right valve of smooth form showing large smooth area of disk succeeded by very closely spaced dichotomous ribs. Unnamed Pliocene strata, San Clemente Island, Calif. $100 \mathrm{~mm}$ high; $101 \mathrm{~mm}$ wide; hinge $48 \mathrm{~mm}$ long. USGS M6503. USNM 235591. (Illustrated by Vedder and Moore, 1976, pl. 3, fig. 3). 

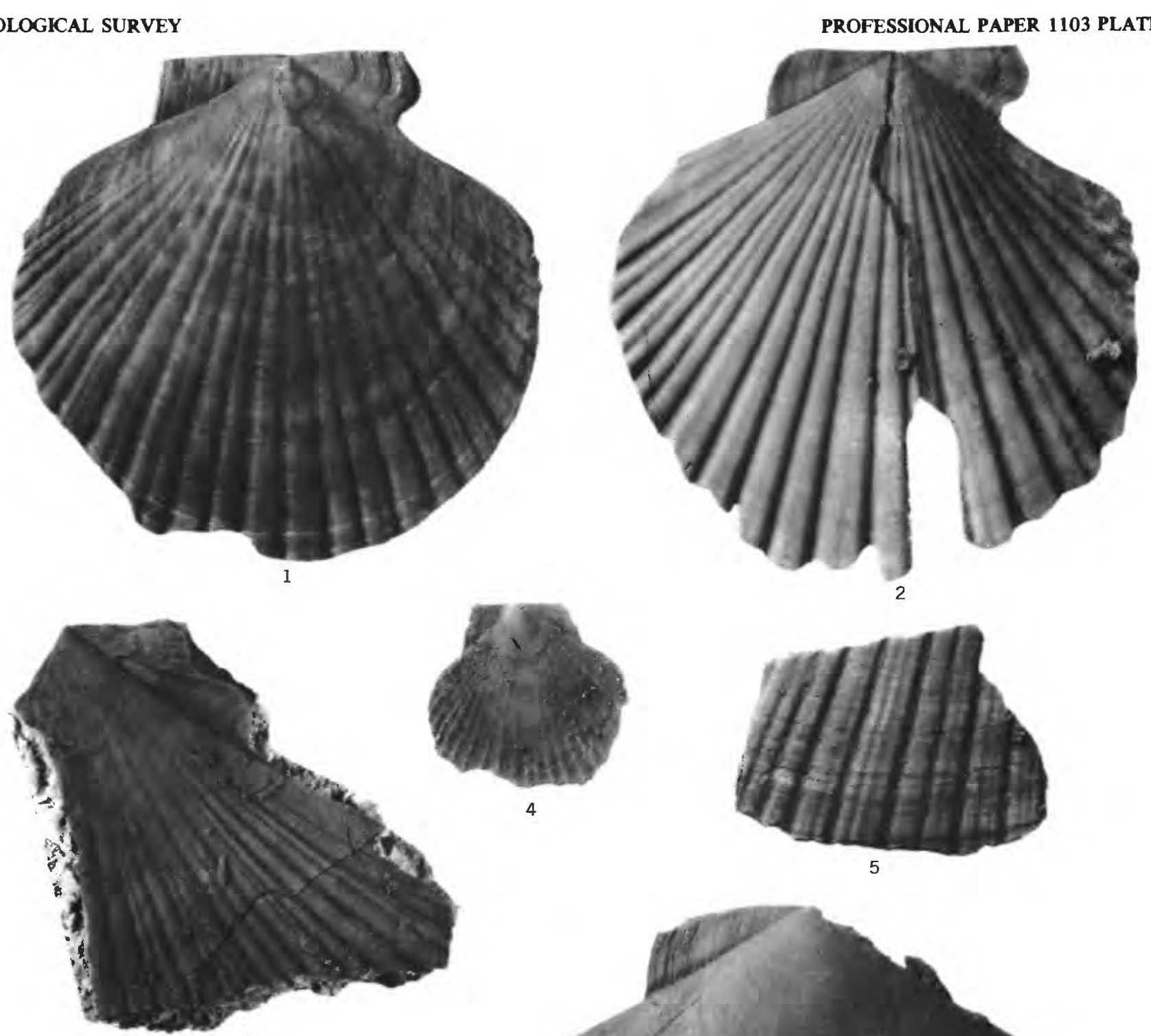

3
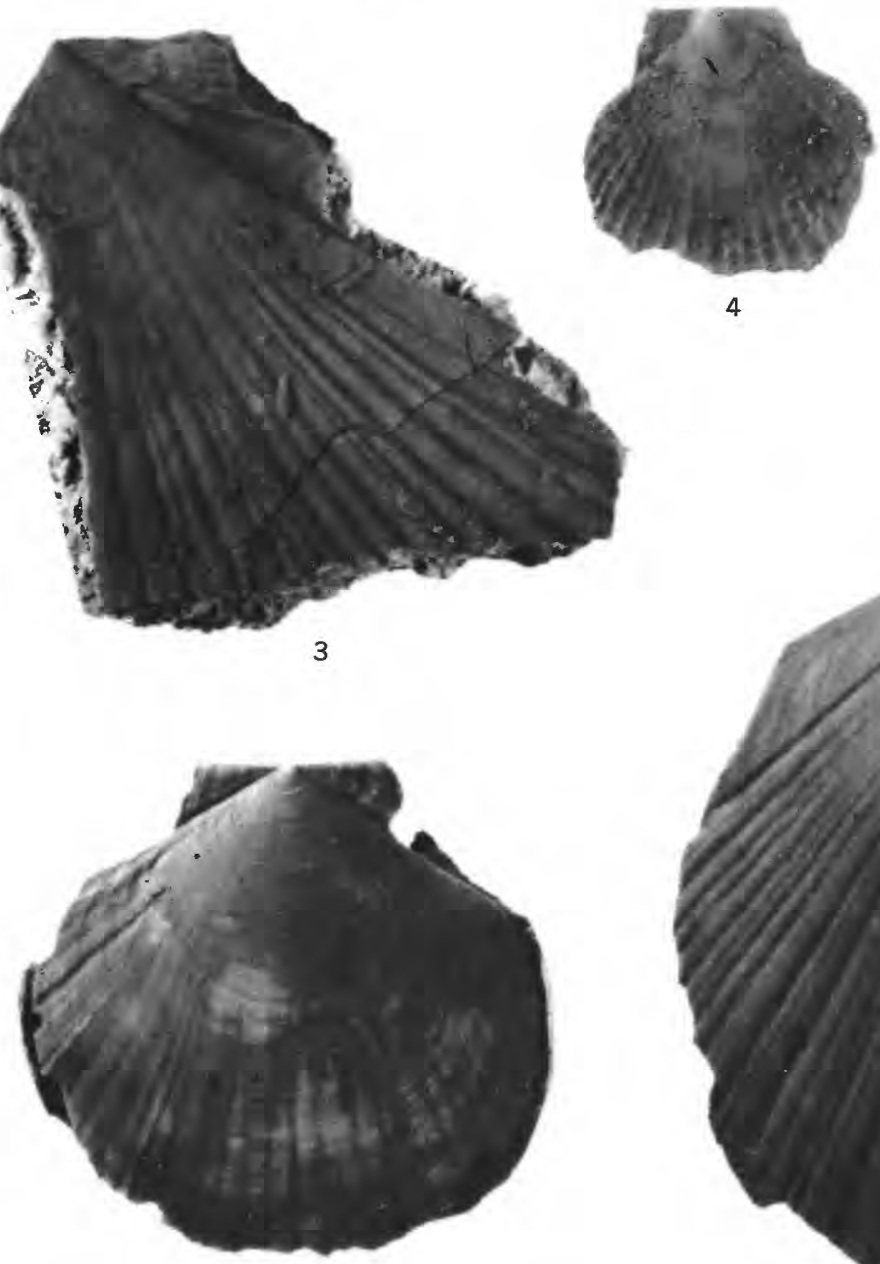

4

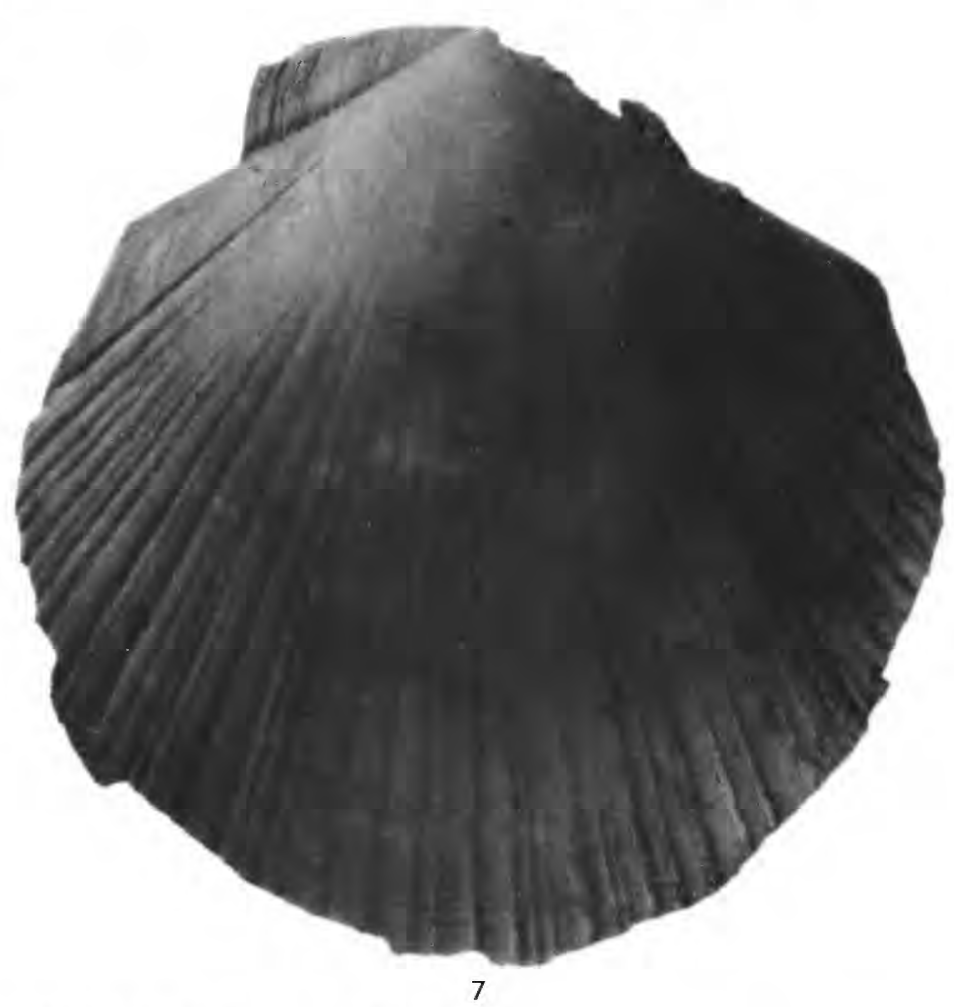

PATINOPECTEN HEALEYI (ARNOLD) 


\section{PLATE 3}

Figures 1-6. Patinopecten healeyi (Arnold).

1. Exterior of right valve of many-ribbed form showing 22 closely spaced dichotomous ribs and unsculptured bands at anterior and posterior margins. San Diego Formation, San Diego, Calif. $132 \mathrm{~mm}$ high; $138 \mathrm{~mm}$ wide. LAM loc. $305 \mathrm{~A}$. LAM $5226, \times 0.66$.

2. Fragment of exterior of right valve showing closely spaced ribs, smooth disk, and wide posterior unsculptured band. Fernando Formation, Newport Beach quadrangle, California. Posterior ear $27 \mathrm{~mm}$ long. USGS M5040. USNM 249742.

3. Fragment of exterior of right valve showing wide very closely spaced ribs. Fernando Formation, Newport Beach quadrangle, California. USGS M5040. USNM 249743.

4. Exterior of incomplete right valve showing narrow dichotomous and trichotomous ribs. Niguel Formation (Pliocene), San Juan Capistrano quadrangle, California. $107 \mathrm{~mm}$ wide. USGS M2096. USNM 249744.

5. Exterior of right valve of many-ribbed form showing 22 closely spaced dichotomous and trichotomous ribs and unsculptured bands at anterior and posterior margins. San Diego Formation, San Diego, Calif. $150 \mathrm{~mm}$ high; $158 \mathrm{~mm}$ wide; hinge $71 \mathrm{~mm}$ long. LAM loc. 107. LAM 5227, $\times 0.60$.

6. Fragment of exterior of right valve showing narrow widely spaced ribs. Fernando Formation, Newport Beach quadrangle, California. USGS M5040. USNM 249745. 

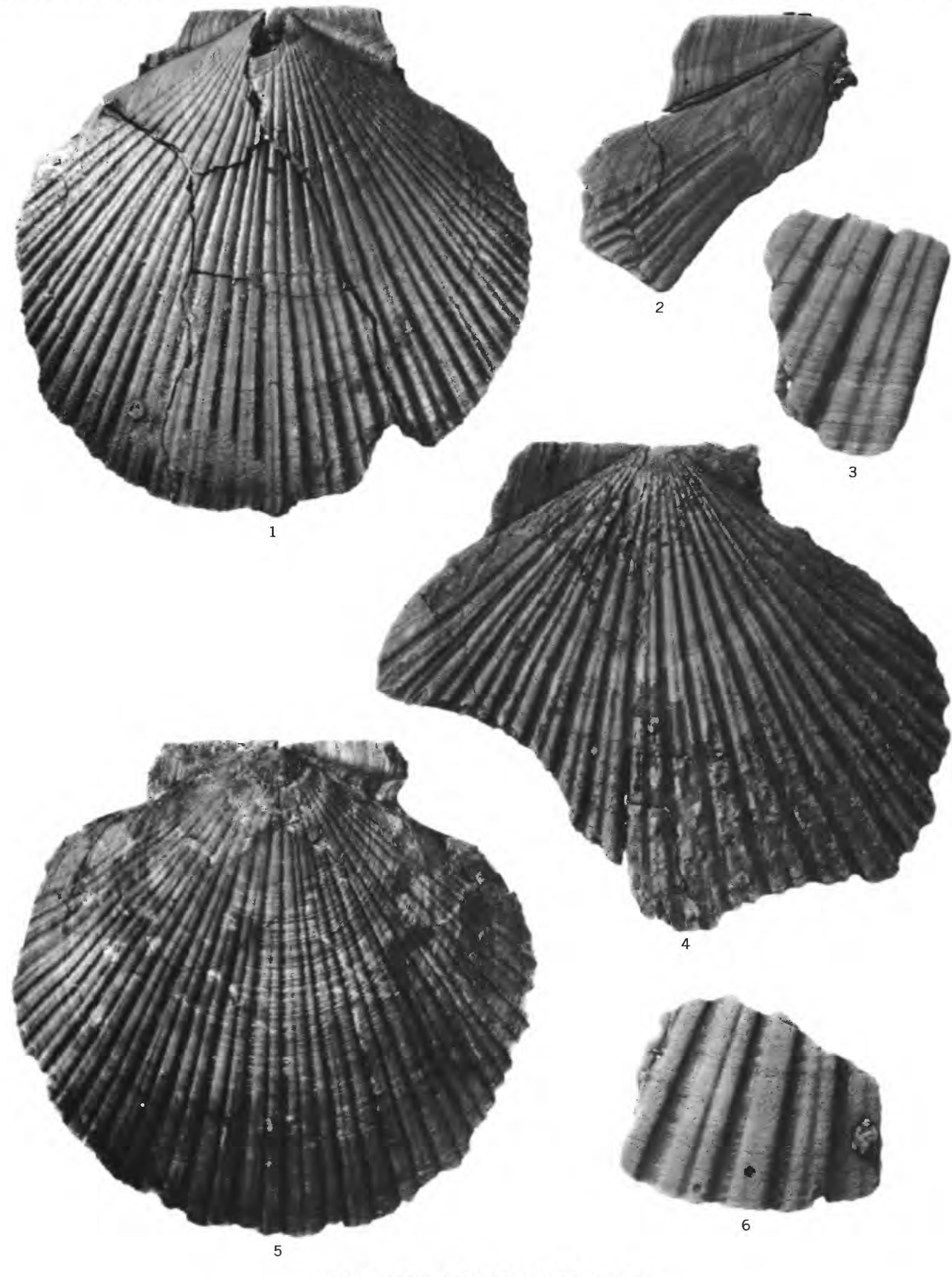

PATINOPECTEN HEALEYI (ARNOLD) 


\section{PLATE 4}

Figures 1-8. Patinopecten healeyi (Arnold).

1. Exterior of incomplete right valve showing subdued deeply dichotomous ribs and wide unsculptured bands at anterior and posterior margins. Fernando Formation, Newport Beach quadrangle, California. $165 \mathrm{~mm}$ wide; hinge $70 \mathrm{~mm}$ long (incomplete). USGS M2753. USNM 249746, $\times 0.66$.

2. Exterior of fragment of right valve showing wide closely spaced dichotomous and trichotomous ribs. Fernando Formation, Newport Beach quadrangle, California. USGS M2753. USNM 249747.

3. Exterior of right valve of double-valved specimen showing smooth ribs near anterior and posterior margins. San Diego Formation, San Diego, Calif. $50 \mathrm{~mm}$ high; $48 \mathrm{~mm}$ wide; hinge $21.5 \mathrm{~mm}$ long. LAM loc. 107. LAM 5228.

4. Exterior of right-valve fragment showing large smooth disk and subdued ribs. Fernando Formation, Newport Beach quadrangle, California. USGS M2753. USNM 249748.

5. Exterior of left valve of double-valved specimen, showing rounded primary ribs. (Same specimen illustrated as fig. 3 .)

6. Enlargement $(x 3)$ of anterior auricle of right valve, illustrated in figure 3 , showing ctenolium.

7. Enlargement (x3) of right anterior auricle showing ctenolium and auricle sculpture. San Diego Formation, San Diego, Calif. Entire specimen: 65 $\mathrm{mm}$ high; $70 \mathrm{~mm}$ wide; hinge $32 \mathrm{~mm}$ long (incomplete); right anterior auricle $17 \mathrm{~mm}$ long. LAM loc. 305. LAM 5229.

8. Exterior of right valve of double-valved specimen showing dichotomous and trichotomous ribs and addition of secondary ribs near ventral margin. (Left valve illustrated, pl. 6, fig. 3.) San Diego Formation, San Diego, Calif. $112 \mathrm{~mm}$ high (incomplete); $123 \mathrm{~mm}$ wide (incomplete); hinge $62 \mathrm{~mm}$ (incomplete). LAM loc. 122, LAM 5230, $\times 0.75$. 

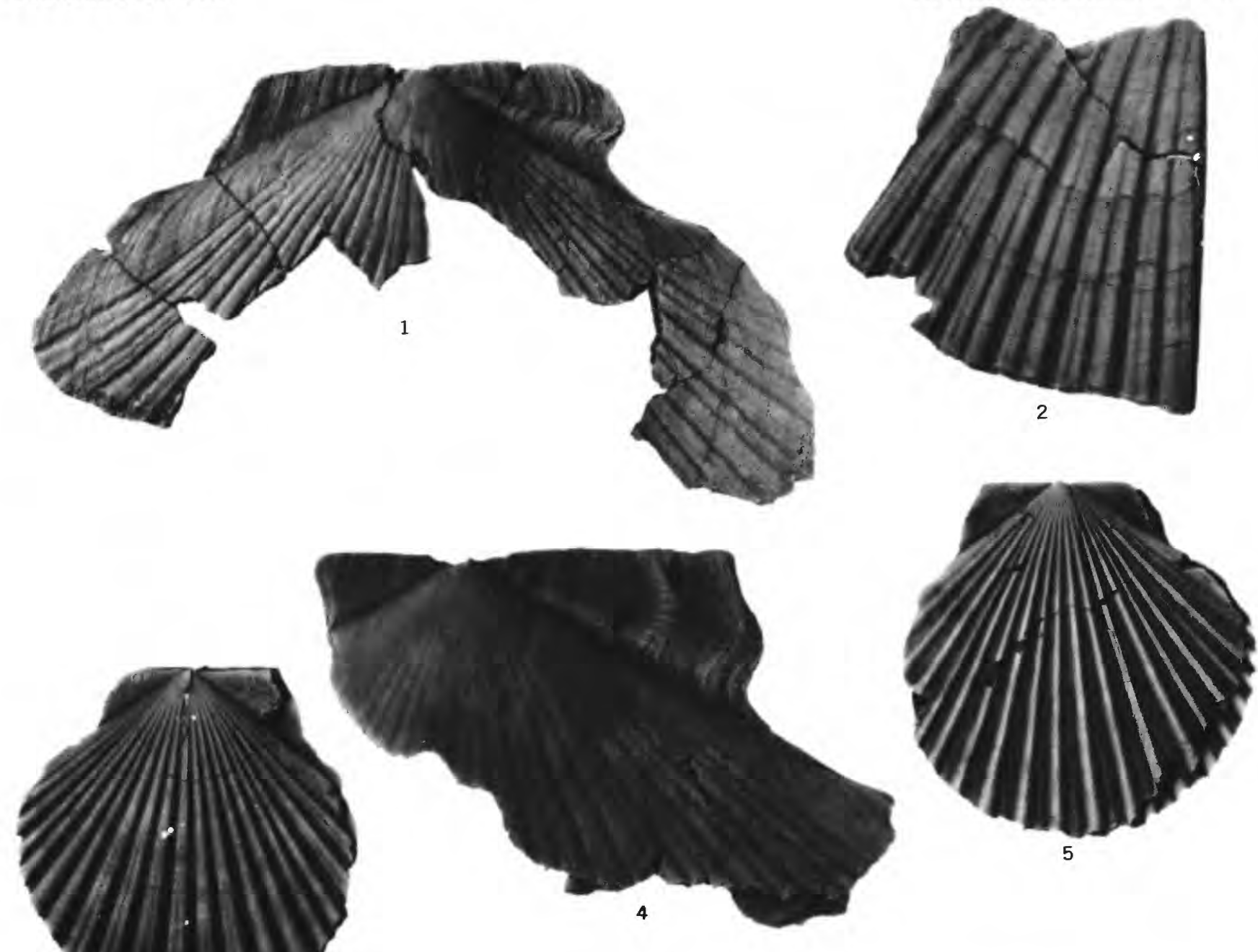
3
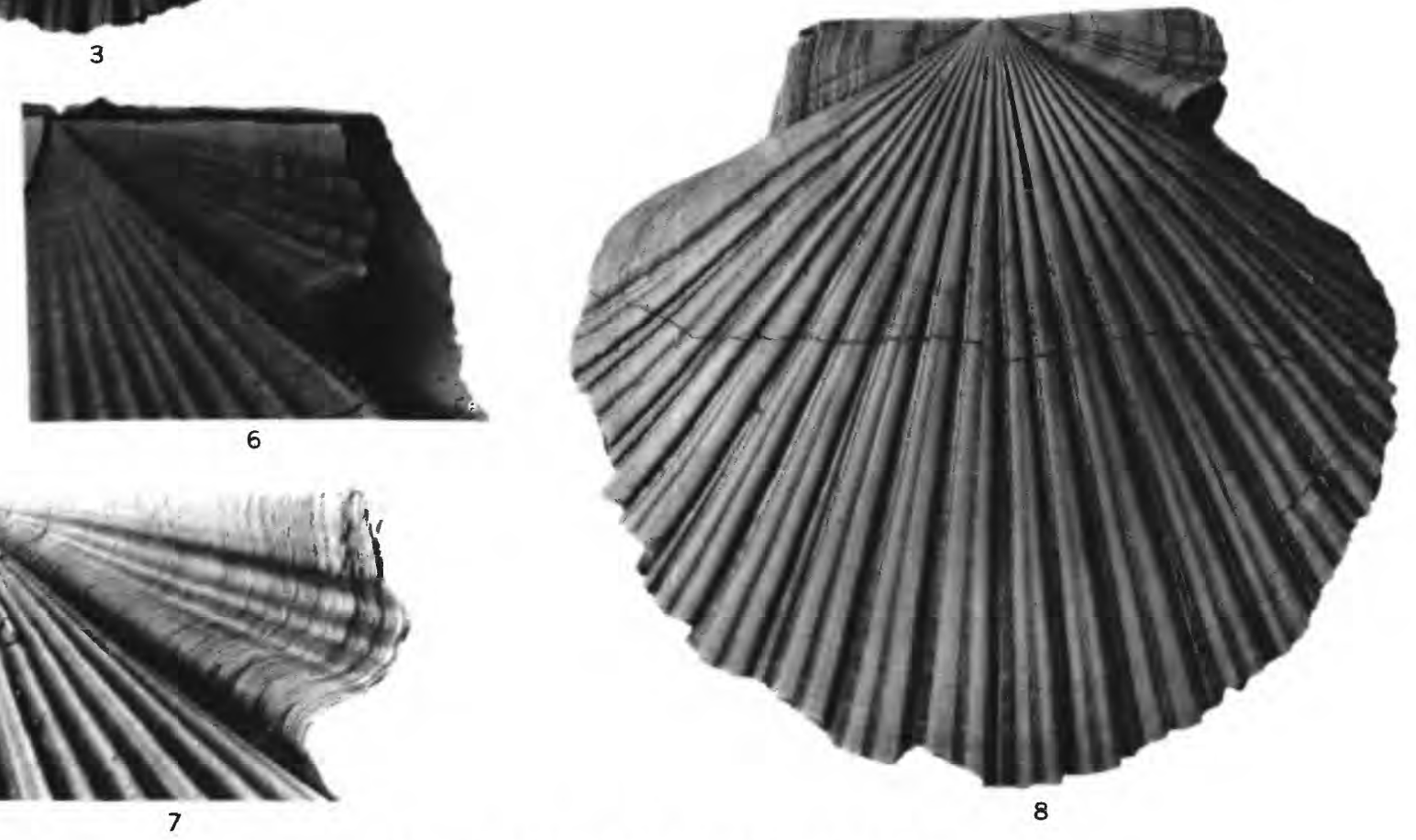

PATINOPECTEN HEALEYI (ARNOLD) 


\section{PLATE 5}

Figures 1-6. Patinopecten healeyi (Arnold).

1. Exterior of left valve showing typical sculpture of alternating primary and secondary ribs. San Diego Formation, San Diego, Calif. $105 \mathrm{~mm}$ high; $106 \mathrm{~mm}$ wide; hinge $51.5 \mathrm{~mm}$ long. LAM loc. 5108. LAM 5231, $\times 0.75$.

2. Exterior of left valve of specimen that has rounded primary ribs but no secondary ribs. San Diego Formation, San Diego, Calif. $87 \mathrm{~mm}$ high; 85 mm wide; hinge $35.5 \mathrm{~mm}$ long. LAM loc. 5108. LAM 5232.

3. Exterior of left valve of probable smooth form showing closely spaced fine primary and secondary ribs and concentric lamellae. Unnamed Pliocene strata, San Clemente Island, Calif. $100 \mathrm{~mm}$ long; $98 \mathrm{~mm}$ high; hinge $47.4 \mathrm{~mm}$ long. USGS M6503. USNM 235593. (Illustrated by Vedder and Moore, 1976, pl. 3, fig. 5.)

4. Electron micrograph of concentric lamellae of left valve showing parallel rather than imbricated pattern. LAM loc. 305 . LAM 5233, $\times 100$.

5. Exterior of left-valve auricles of double-valved specimen. (Right-valve auricles illustrated, pl.7, fig. 3). San Diego Formation, San Diego, Calif. Hinge $63 \mathrm{~mm}$ long. LAM loc. 5108. LAM 5234.

6. Exterior of left valve showing squaring of ribs toward ventral margin and fine concentric lamellae. San Diego Formation, San Diego, Calif. $94 \mathrm{~mm}$ high; $95 \mathrm{~mm}$ wide; hinge $42 \mathrm{~mm}$ long (incomplete). LAM loc. 5108. LAM 5235 . 
GEOLOGICAL SURVEY
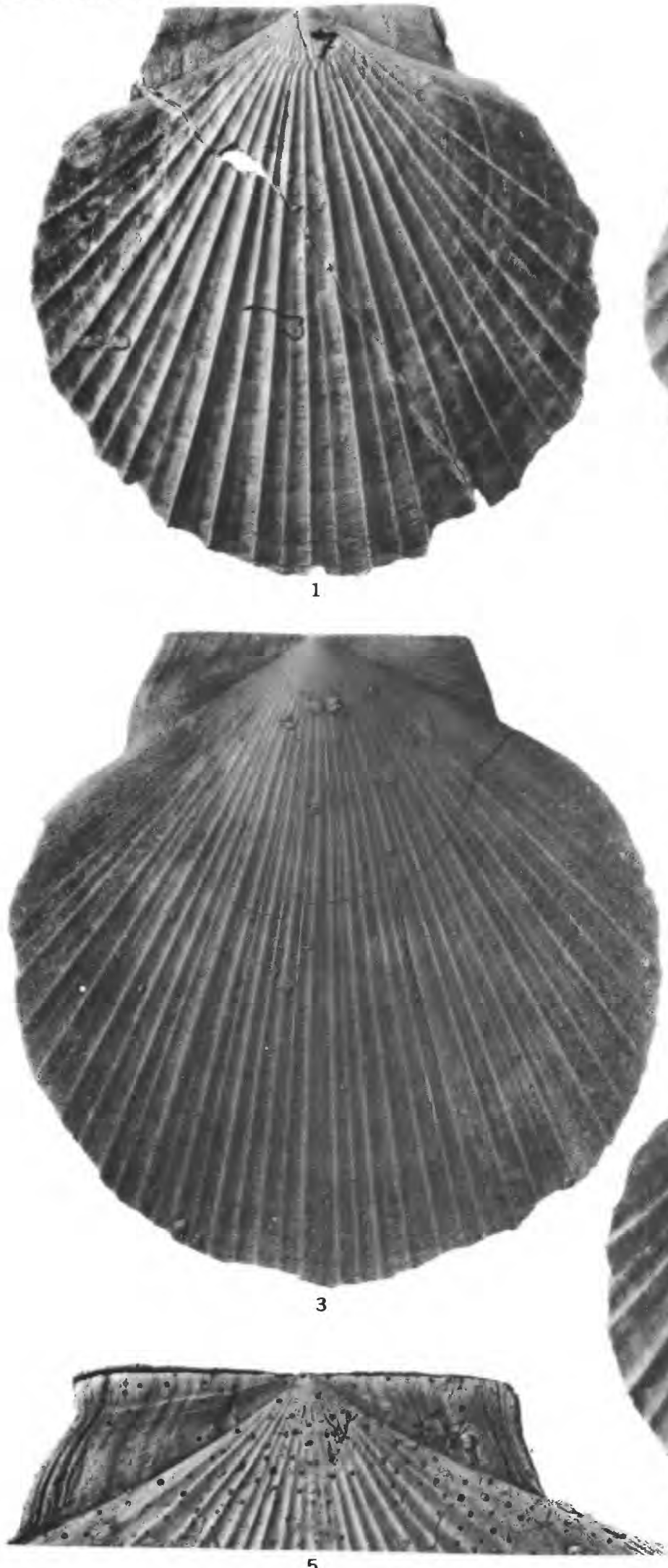

PROFESSIONAL PAPER 1103 PLATE 5
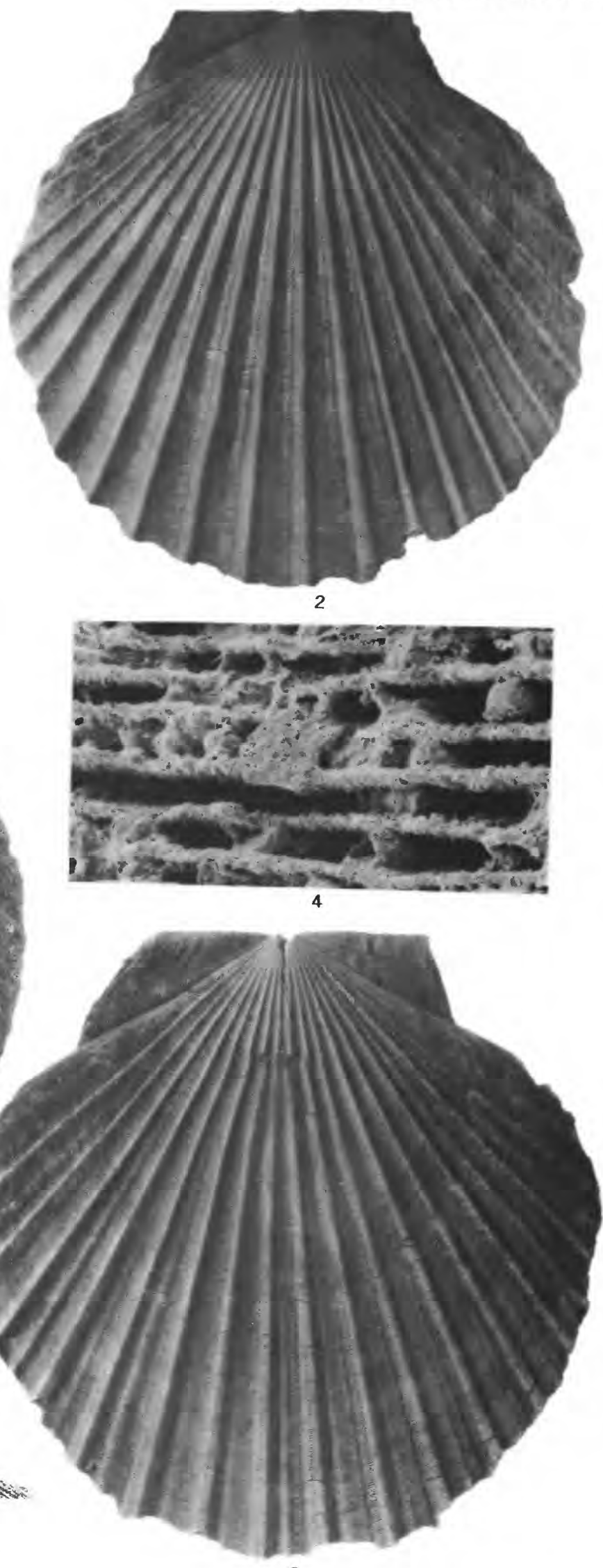


\section{PLATE 6}

Figures 1-7. Patinopecten healeyi (Arnold), San Diego Formation, San Diego, Calif.

1. Exterior of left-valve auricles showing anterior fold and subdued riblets. (Same specimen illustrated pl. 9, fig. 1). Hinge $94 \mathrm{~mm}$ long; anterior auricle $49 \mathrm{~mm}$ long; posterior auricle $45 \mathrm{~mm}$ long. LAM loc. 122. LAM 5236.

2. Exterior of left-valve anterior auricle showing fold, riblets, and concentric sculpture, and of anterior disk showing imbricated microsculpture. Hinge $44 \mathrm{~mm}$ long; anterior auricle $23.5 \mathrm{~mm}$ (maximum length). LAM loc. 122. LAM 5237, $\times 3$.

3. Exterior of left valve of double-valved specimen showing a small rib running down the center of some of the primary ribs and two secondary ribs in the interspaces near the anterior margin. $110 \mathrm{~mm}$ high; $118 \mathrm{~mm}$ wide; $60 \mathrm{~mm}$ high. LAM loc. 122 . LAM $5230, \times 0.75$. (Right valve illustrated, pl. 4, fig. 8.)

4. Interior of left-valve hinge area showing ridges bordering resilial pit and auricular denticles. Hinge $42 \mathrm{~mm}$ long. LAM loc. 5108. LAM 5238.

5. Interior of left-valve hinge area showing ridges and grooves bordering resilial pit. Hinge $52.5 \mathrm{~mm}$ long. LAM loc. 5108. LAM 5239.

6. Interior of left-valve hinge area showing ridges and grooves bordering resilial pit. Hinge $68.3 \mathrm{~mm}$ long. LAM loc. 5108. LAM 5240.

7. Exterior of left valve of double-valved specimen showing anterior unsculptured band and overlap of larger right valve along ventral margin. (Right-valve auricles illustrated, pl. 13, fig. 1). $140 \mathrm{~mm}$ high; $150 \mathrm{~mm}$ wide; hinge $75 \mathrm{~mm}$ long (incomplete). LAM loc. 5108. LAM 5241, $\times 0.66$. 


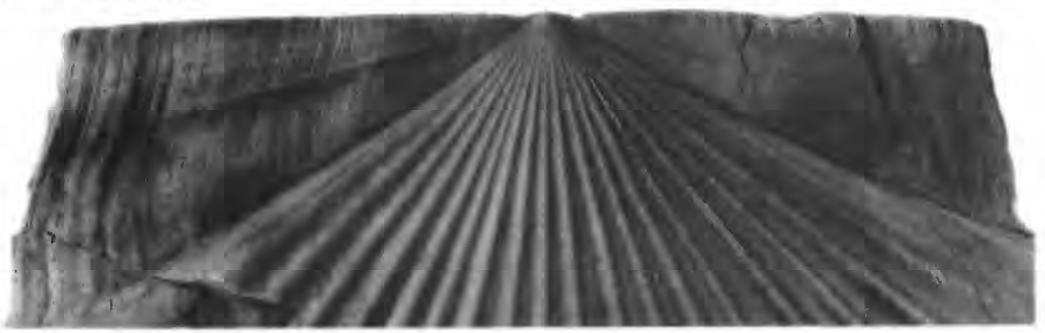

1

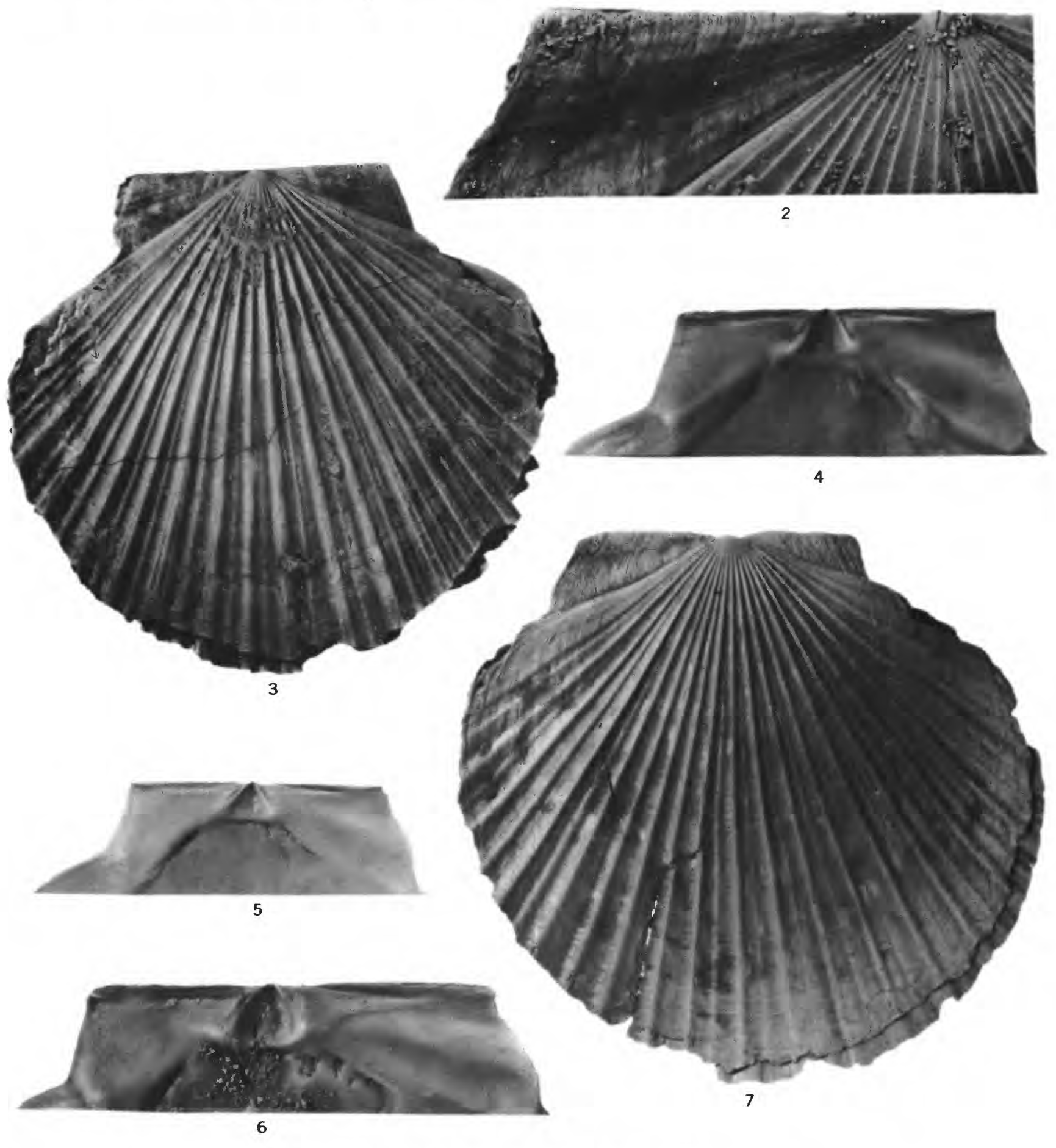

PATINOPECTEN HEALEYI (ARNOLD) 


\section{PLATE 7}

Figures 1-5. Patinopecten healeyi (Arnold).

1. Exterior of left valve showing square, ribbed primaries and two times of breakage and subsequent repair of shell. Niguel Formation, San Juan Capistrano quadrangle, California. $97 \mathrm{~mm}$ high; $103 \mathrm{~mm}$ wide; hinge 52 mm long (incomplete). USGS M2098. USNM 249749.

2. Exterior of fragment of left valve showing multiple secondary ribs at anterior margin. Fernando Formation, Newport Beach quadrangle, California. USGS M2753. USNM 249750.

3. Exterior of right valve auricles of double-valved specimen showing sculpture and the enlargement of left anterior auricle opposing the right anterior auricle. (Left-valve auricles illustrated, pl. 5, fig. 5.) San Diego Formation, San Diego, Calif. Hinge $63 \mathrm{~mm}$ long. LAM loc. 5108. LAM 5234 .

4. Exterior of fragment of left valve showing wide square primaries and doubled secondaries. Niguel Formation, San Juan Capistrano quadrangle, California. USGS M2096. USNM 249751.

5. Exterior of left valve showing narrow ribs on disk that are flat and broad at the ventral margin and showing marked enlargement of anterior auricle. San Diego Formation, San Diego, Calif. $127 \mathrm{~mm}$ high (incomplete); $130 \mathrm{~mm}$ wide (incomplete); hinge $60.4 \mathrm{~mm}$ long. USGS M3627. USNM $249752, \times 0.75$. 


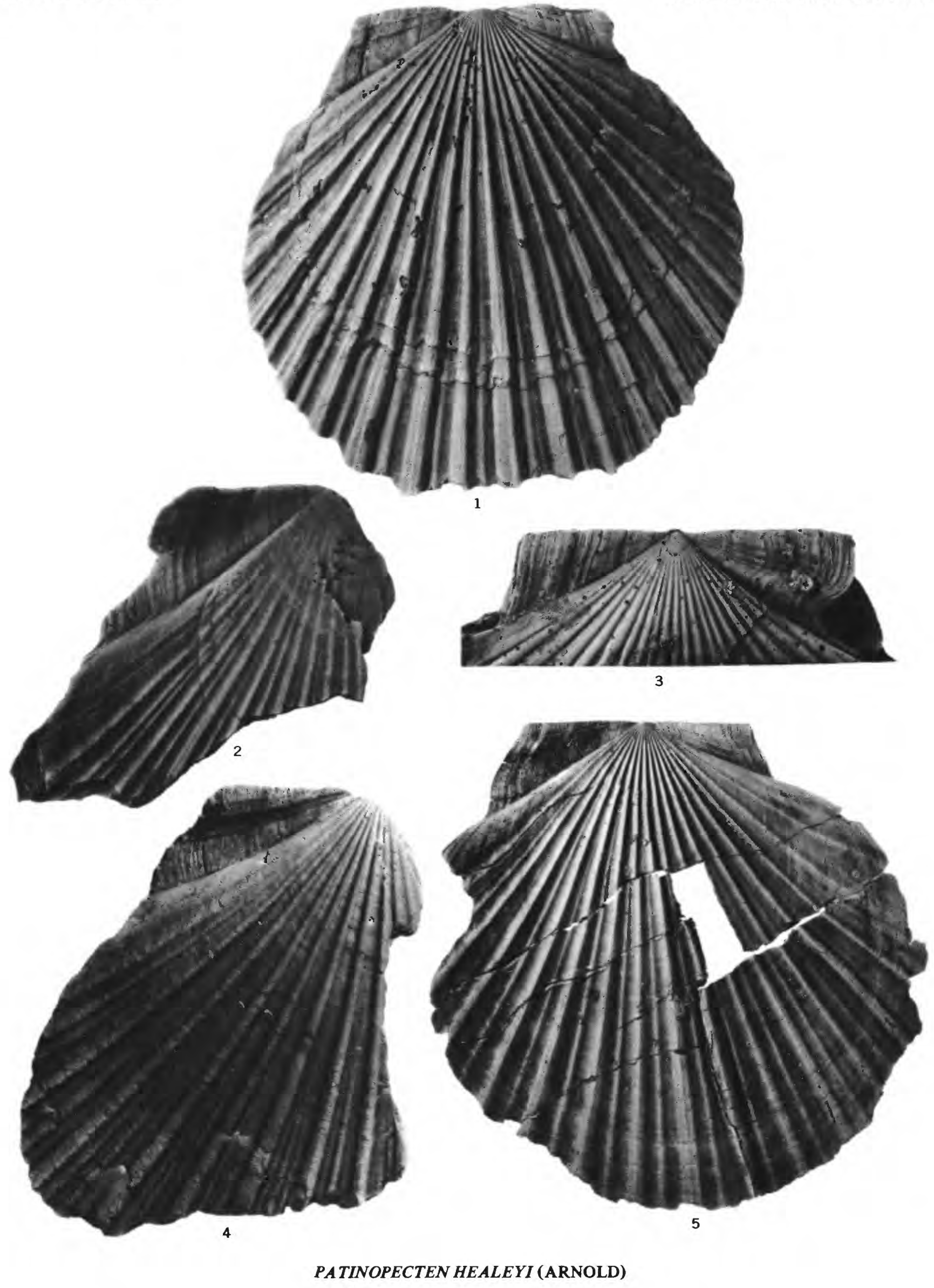




\section{PLATE 8}

Figures 1-6. Patinopecten healeyi (Arnold), San Diego Formation, San Diego, Calif.

1. Exterior of left valve showing square primaries, some ribbed, and enlargement of anterior auricle. $128 \mathrm{~mm}$ high; hinge $66 \mathrm{~mm}$ long. LAM loc. 5108. LAM 5242, $\times 0.75$.

2. Interior of left valve showing hinge area and auricular denticles. Entire specimen $116 \mathrm{~mm}$ high; $120 \mathrm{~mm}$ wide; hinge $55 \mathrm{~mm}$ long. LAM loc. 5108. LAM 5243.

3. Exterior of left valve showing multiple times of breakage and subsequent repair of shell. (Same specimen illustrated as fig. 5.) $140 \mathrm{~mm}$ high; 150 $\mathrm{mm}$ wide; hinge $68 \mathrm{~mm}$ long. LAM loc. 5108 . LAM 5244, $\times 0.66$.

4. Exterior of left valve showing ribbed primaries, some narrow and some round secondaries, one double secondary near anterior margin, and enlarged anterior auricle. $140 \mathrm{~mm}$ high; $147 \mathrm{~mm}$ wide; hinge $70 \mathrm{~mm}$ long. LAM loc. 5108. LAM $5245, \times 0.66$.

5. Interior of left-valve hinge area. Note grooves and double ridges bordering resilial pit. (Same specimen illustrated as fig. 3.) Hinge $68 \mathrm{~mm}$ long (incomplete)

6. Exterior of left valve showing wide, ribbed primaries, narrow to widely rounded secondaries, fine ribs at anterior margin, breakage and repair of shell, and enlarged anterior auricle. $147 \mathrm{~mm}$ high; $159 \mathrm{~mm}$ wide; hinge $80 \mathrm{~mm}$ long. LAM loc. 5108 . LAM $5246, \times 0.60$. 


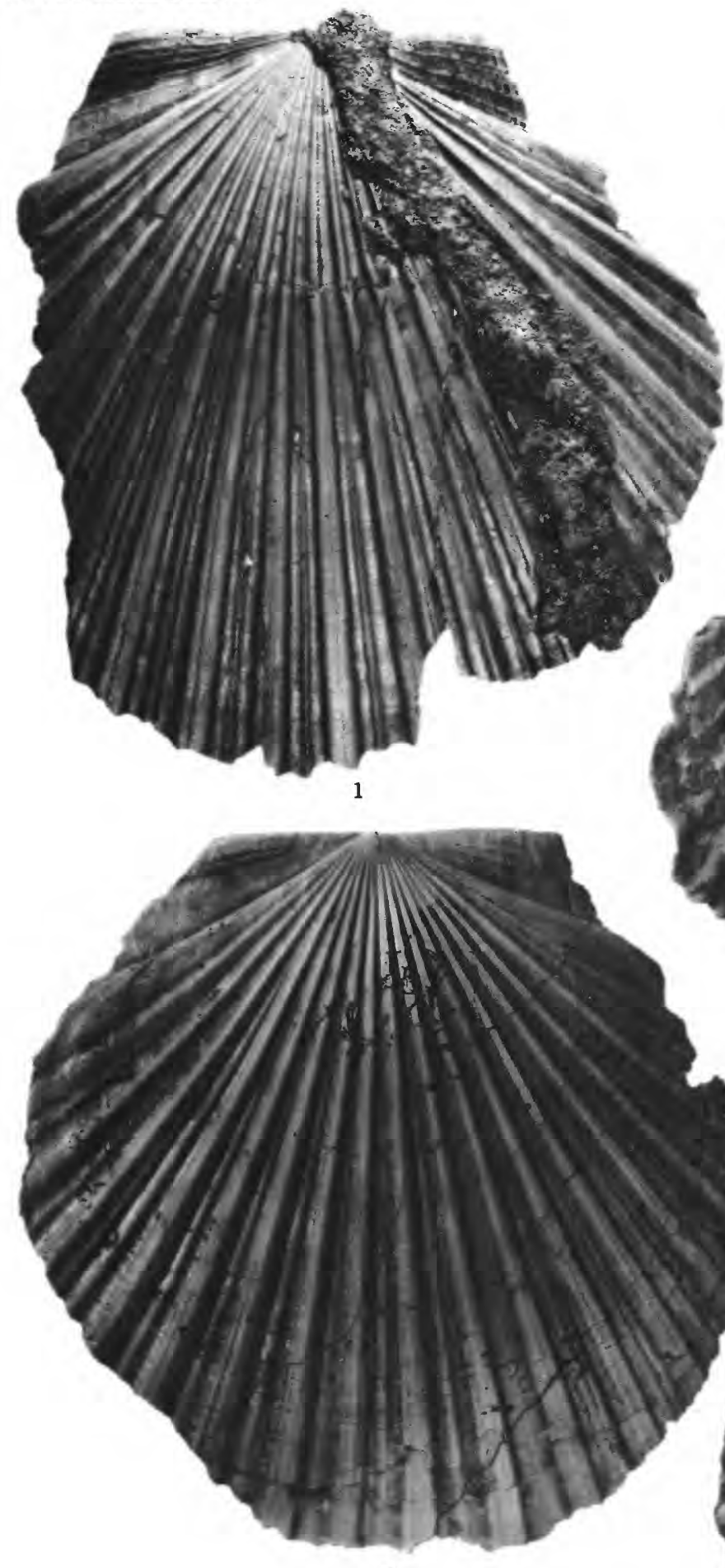

4

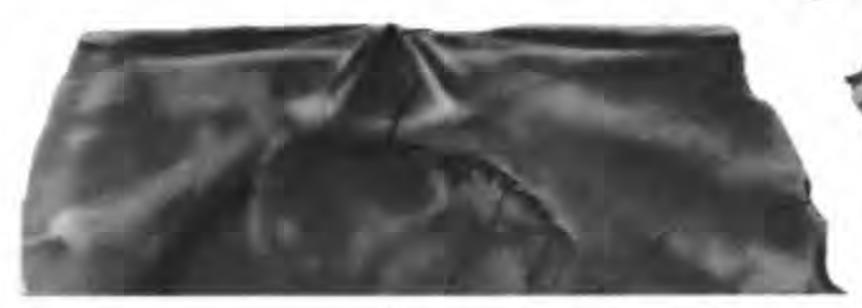

5

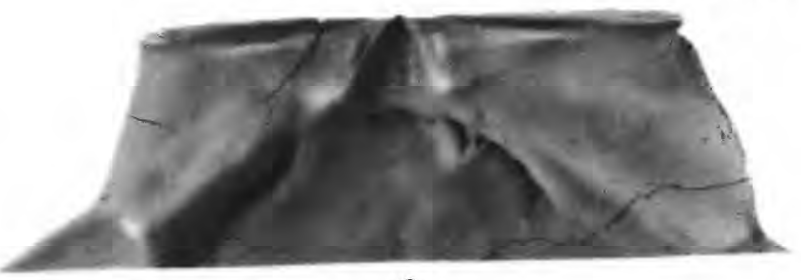

2
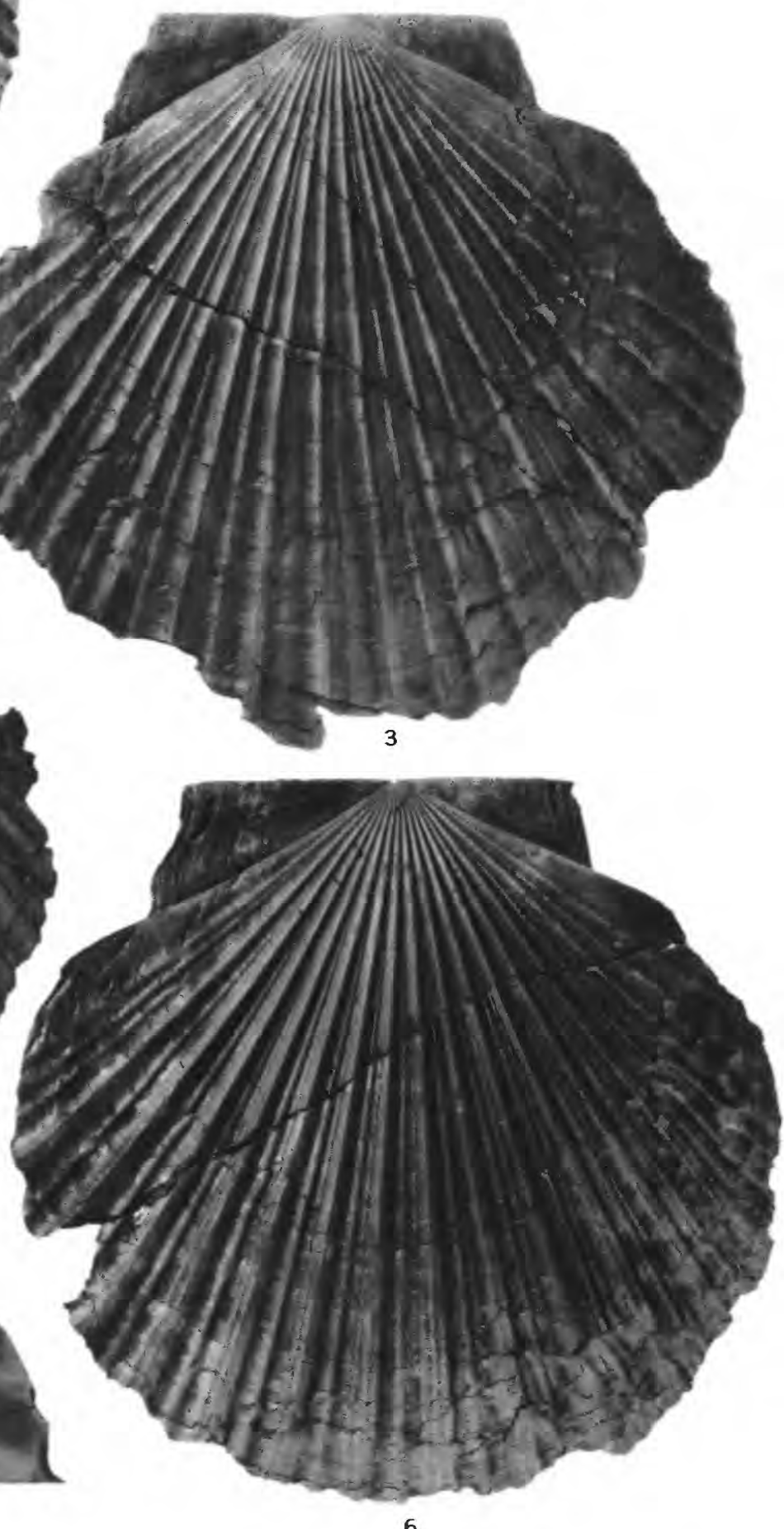

PATINOPECTEN HEALEYI (ARNOLD) 


\section{PLATE 9}

Figures 1-7. Patinopecten healeyi (Arnold).

1. Interior of left valve showing hinge area and anterior auricular denticle. (Same specimen illustrated, pl. 6, fig. 1) San Diego Formation, San Diego, Calif. Hinge $92 \mathrm{~mm}$ long. LAM loc. 122. LAM 5236.

2. Interior of right-valve hinge area. San Diego Formation, San Diego, Calif. Hinge $77 \mathrm{~mm}$ long (incomplete). USGS loc. M3628. USNM 249753.

3. Interior of left-valve hinge area. San Diego Formation, San Diego, Calif. Hinge $78 \mathrm{~mm}$ long. USGS loc. M3628. USNM 249754.

4. Fragment of exterior of left valve showing wide flat primaries and some narrow and some wide flat secondaries. Niguel Formation, San Juan Capistrano quadrangle, California. USGS loc. M2096. USNM 249755.

5. Interior of right-valve hinge area showing thickened posterior ridge. San Diego Formation, San Diego, Calif. Hinge $55 \mathrm{~mm}$ long. LAM loc. 122. LAM 5247.

6. Interior of right-valve hinge area showing thickened posterior ridge. San Diego Formation, San Diego, Calif. Hinge 53 mm long. LAM loc. 122. LAM 5248.

7. Exterior of left valve showing subdued ribs near ventral margin and enlarged anterior auricle. San Diego Formation, San Diego, Calif. $120 \mathrm{~mm}$ high; $130 \mathrm{~mm}$ wide; hinge $59 \mathrm{~mm}$ long. LAM loc. 122 . LAM 5249, $\times 0.75$. 


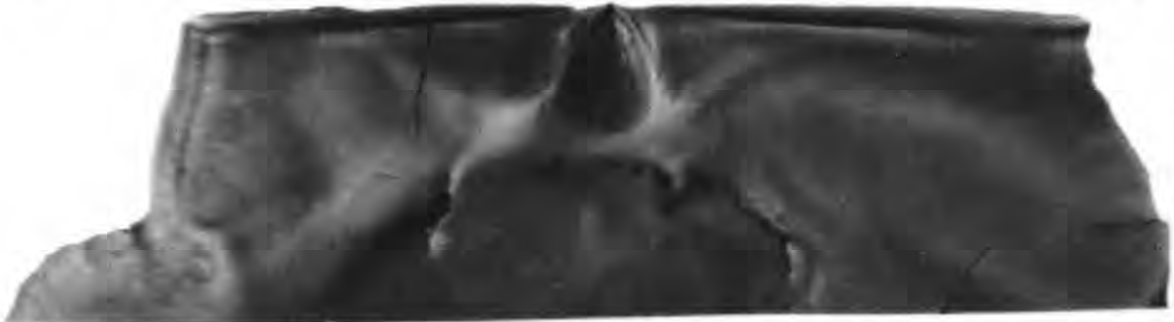

1

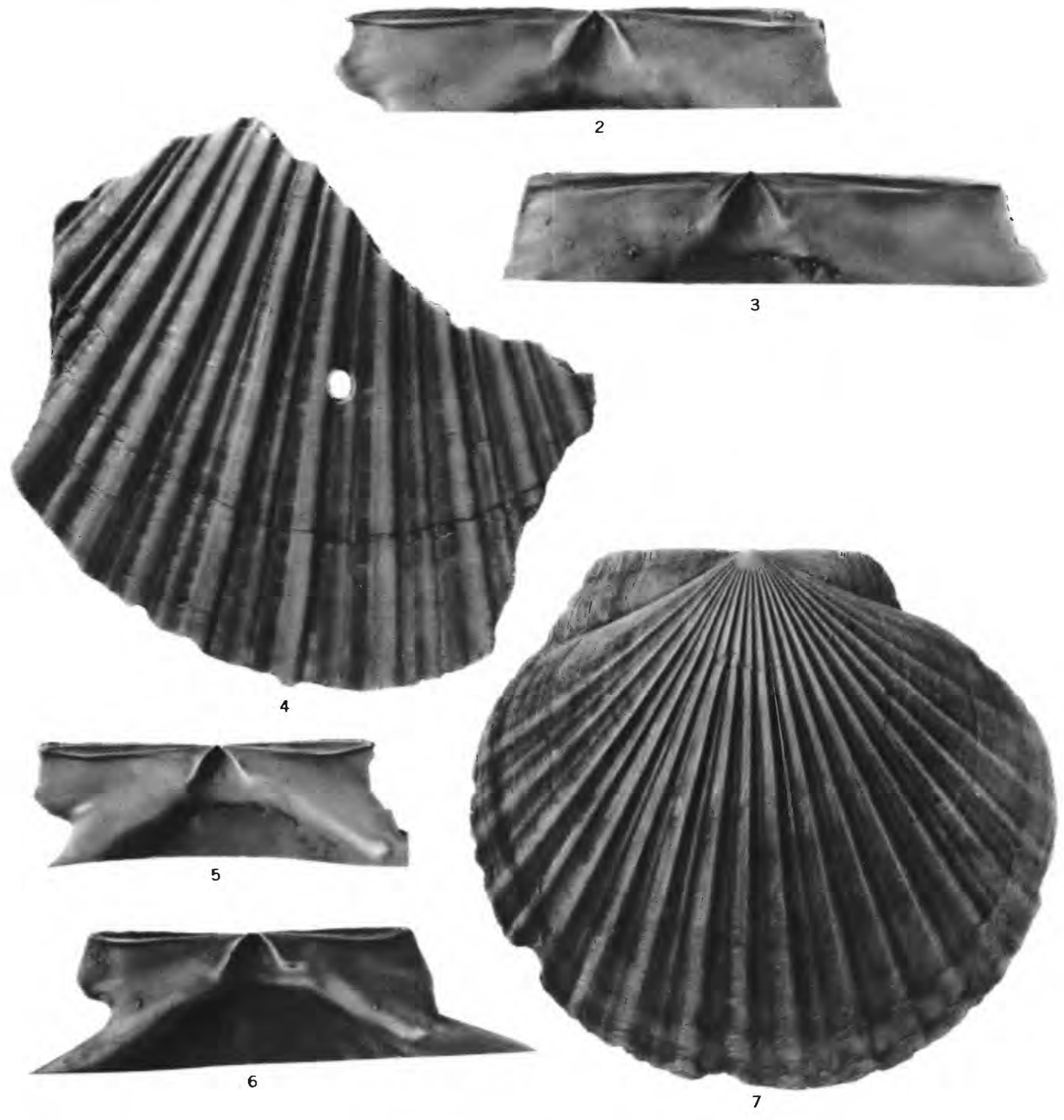

PATINOPECTEN HEALEYI (ARNOLD) 


\section{PLATE 10}

Figures 1-5. Patinopecten healeyi (Arnold), San Diego Formation, San Diego, Calif.

1. Exterior of small left valve enlarged to show imbricated microsculpture. Note also fine primary ribs and few secondary ribs, $37 \mathrm{~mm}$ high; $36 \mathrm{~mm}$ wide (incomplete). LAM loc. 107. LAM 5250, $\times 2.50$.

2. Interior of right-valve hinge area. Hinge $92 \mathrm{~mm}$ long. LAM loc. 122. LAM 5251.

3. Exterior of small left valve enlarged to show imbricated and lamellar microsculpture and enlarged anterior auricle. Note also rounded primary ribs and few secondary ribs. $37 \mathrm{~mm}$ high; $38 \mathrm{~mm}$ wide; hinge $18.8 \mathrm{~mm}$ long. LAM loc. 107. LAM 5252, ×2.50.

4. Exterior of juvenile left valve enlarged to show imbricated microsculpture (see also pls. 11-13 for electron micrographs of same specimen). 21.4 $\mathrm{mm}$ high; $20.5 \mathrm{~mm}$ wide; hinge $10.1 \mathrm{~mm}$ high. LAM loc. 107. LAM 5253, $\times 3$.

5. Electron micrograph of imbricated microsculpture on specimen illustrated in figure 4 . Note that lamellae are not imbricated where they cross ribs. 


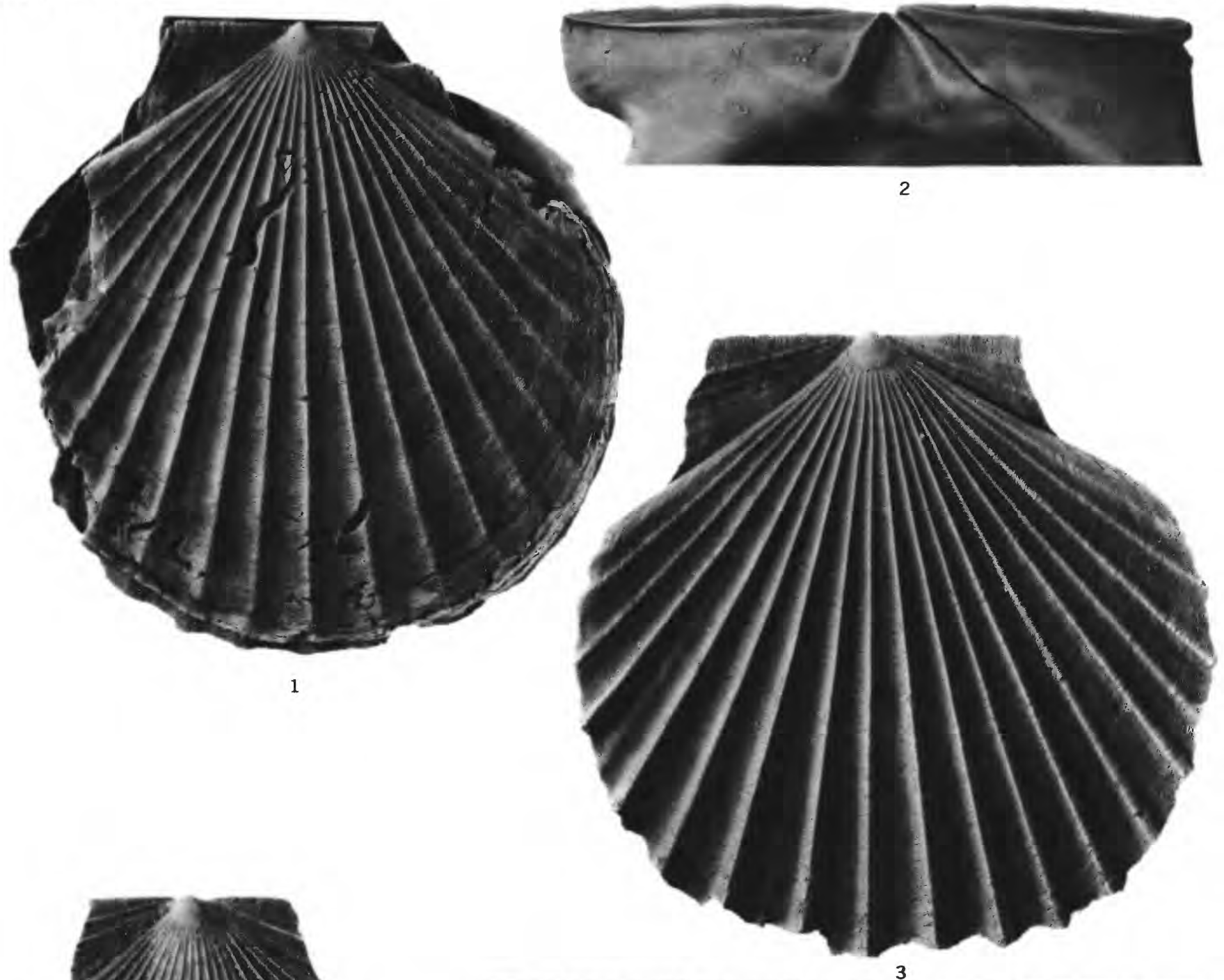

3






\section{PLATE 11}

Figures 1-3. Patinopecten healeyi (Arnold), San Diego Formation, San Diego, Calif. Electron micrographs of left valve illustrated, pl. 10, fig. 4. The specimen was scanned from the dorsal to the ventral margin with fig. 1 showing the dorsal margin and fig. 3 the area about one-third the distance from the dorsal to the ventral margin (pl. 12 continues the scan).

1. The microsculpture consists of longitudinal ridges that are not parallel with the primary ribs.

2. The microsculpture now consists of longitudinal ridges that are nearly parallel with the primary ribs and of concentric ridges that cross the primary ribs.

3. Concentric ridges are prominent between ribs and are starting to become imbricated. 


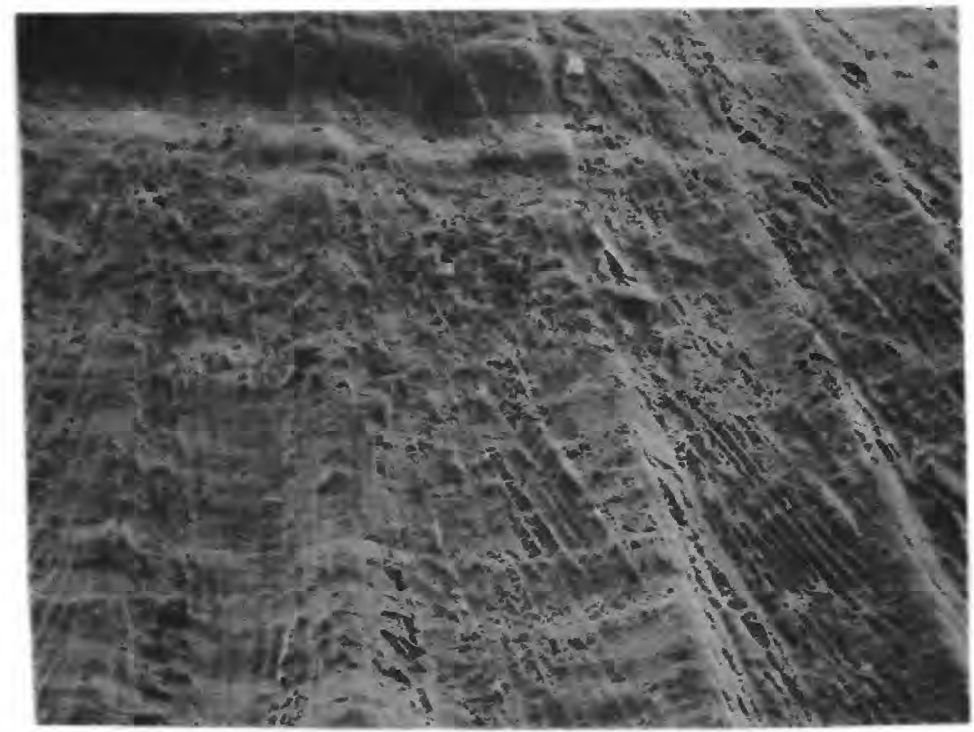

1

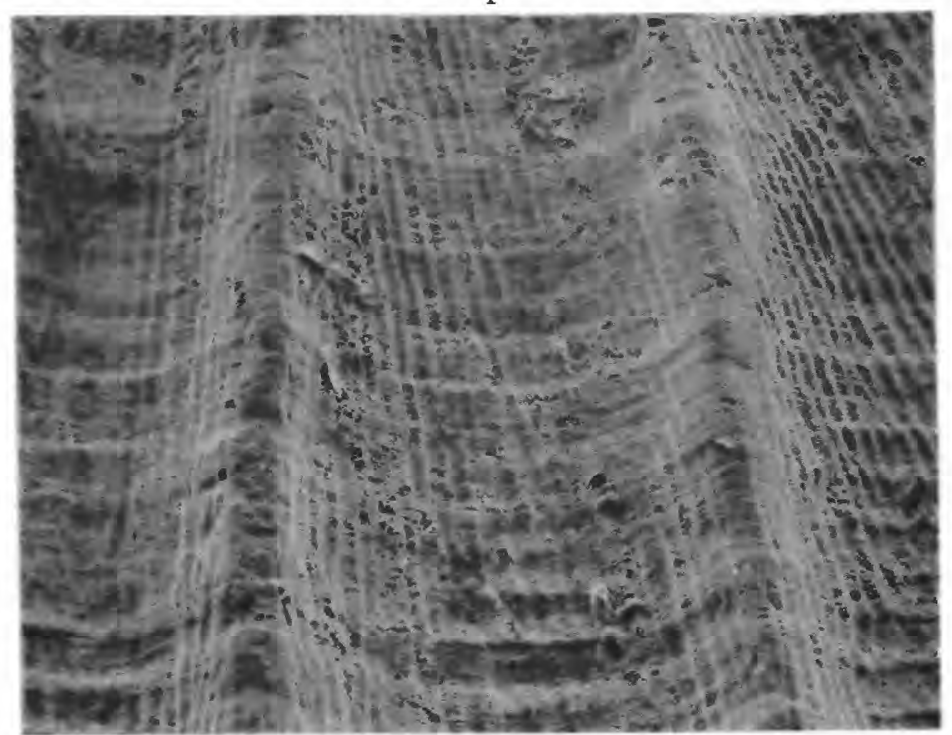

2

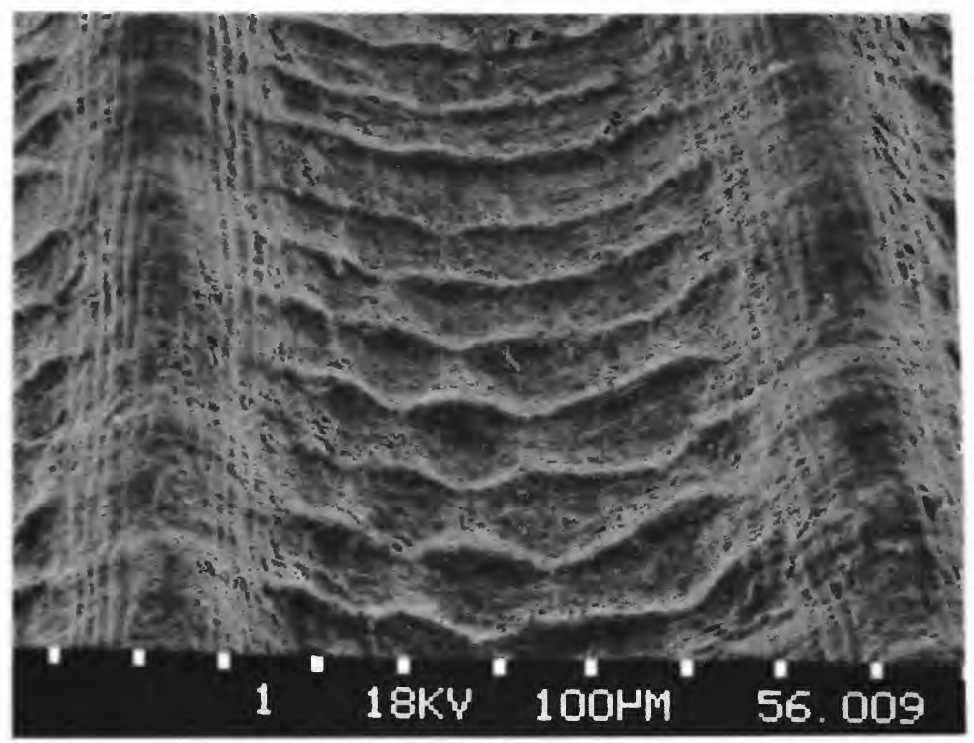

PATINOPECTEN HEALEYI (ARNOLD) 


\section{PLATE 12}

Figures 1-3. Patinopecten healeyi (Arnold), San Diego Formation, San Diego, Calif. Electron micrographs of left valve illustrated, pl. 10, fig. 4. The specimen was scanned from the dorsal to the ventral margin with fig. 1 representing the midportion of the shell and fig. 3 the shell near the ventral margin (pl. 11 shows dorsal scan).

1. The concentric ridges are now loosely imbricated between the ribs.

2. The concentric ridges are loosely imbricated at the top of the picture but barely scalloped near the bottom of the picture.

3. The concentric ridges are tightly imbricated between the primary ribs. 


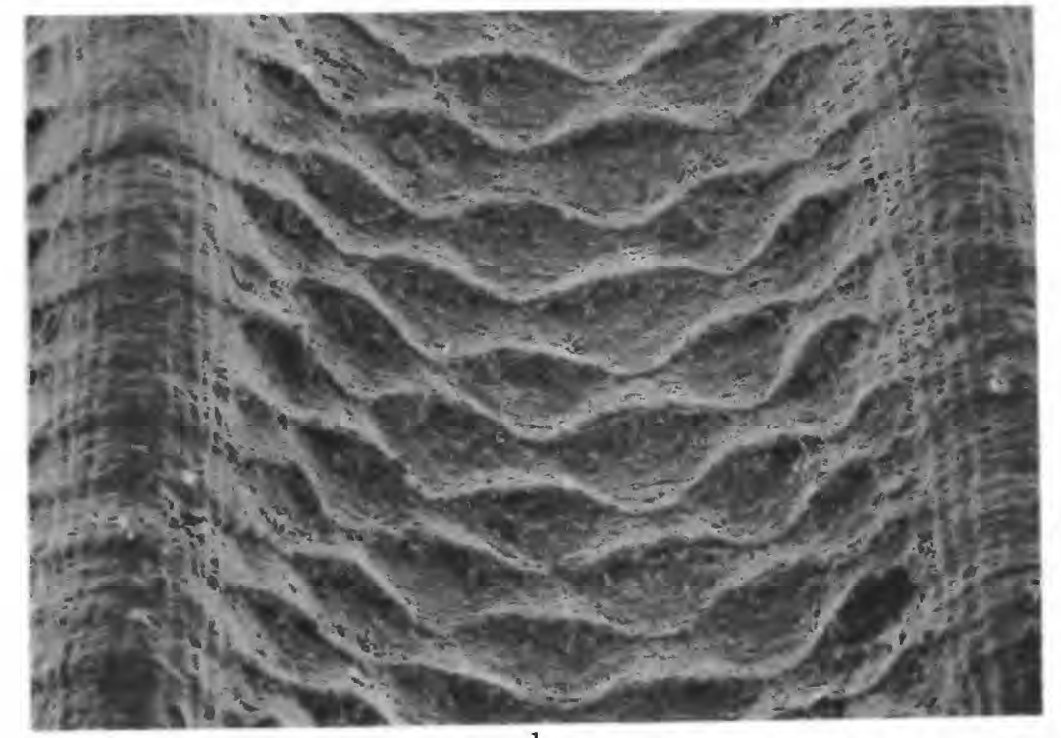

1

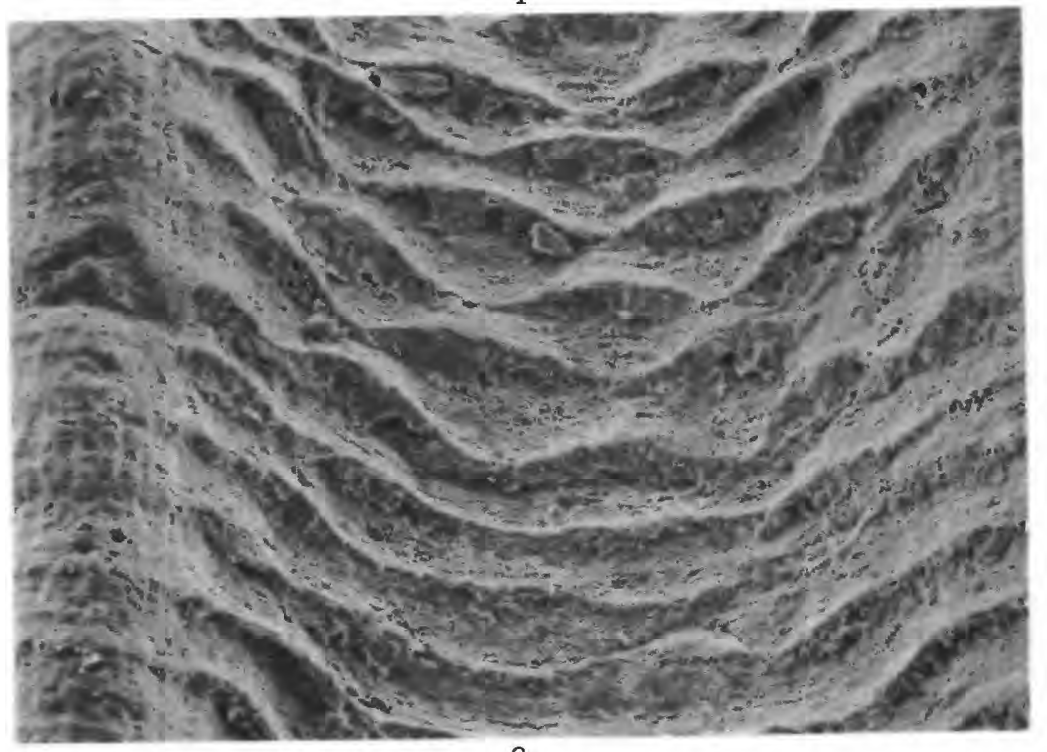

2

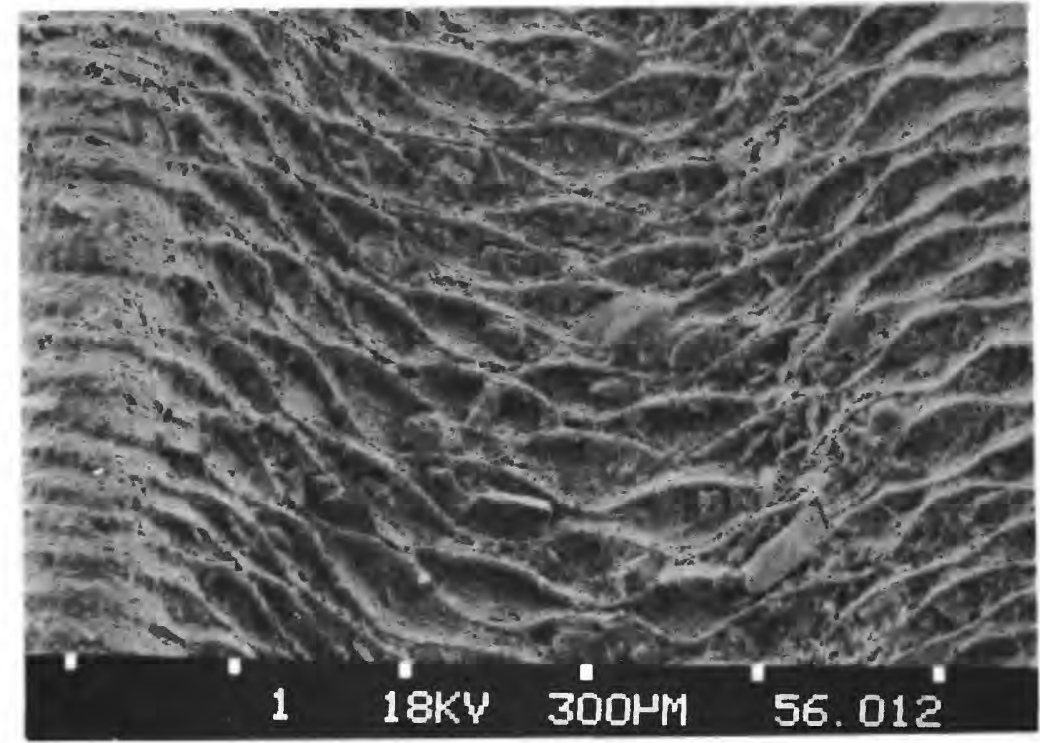

3

PATINOPECTEN HEALEYI (ARNOLD) 


\section{PLATE 13}

Figures 1, 2, 5. Patinopecten healeyi (Arnold), San Diego Formation, San Diego, Calif.

1. Right-valve auricles of double-valve specimen showing strong flexure of byssus. Note also the unsculptured band at both the anterior and posterior margins. (Left valve of same specimen illustrated, pl. 6, fig. 7.) Hinge $62.4 \mathrm{~mm}$ long. LAM loc. 5108, LAM 5241.

2. Dorsal view of hinge of double-valved specimen showing relative inflation of valves and strong flexure of left anterior auricle toward right anterior auricle byssus. (Same specimen illustrated, pl. 14, fig. 3; pl. 15, figs. 2 . 3.) Hinge $95 \mathrm{~mm}$ long. LAM loc. 107. LAM 5254, $\times 0.66$.

5. Electron micrograph of portion of anterior auricle of left valve, illustrated pl. 10, fig. 4 , and pls. 11 and 12 , showing closely spaced lamellae.

3, 4, 6. Patinopecten lohri (Hertlein), holotype (UCMP 12081). Tinaquaic Sandstone Member, Sisquoc Formation, near Foxen Canyon, Calif.

3. Right valve of holotype showing wide, high, dichotomous primary ribs with a wide rounded secondary rib in every interspace. $87 \mathrm{~mm}$ high; 88 $\mathrm{mm}$ wide, hinge $47 \mathrm{~mm}$ long.

4. Dorsal view of holotype showing relative inflation of valves.

6. Left valve of holotype showing strong, rounded primary ribs that are dichotomous near ventral margin, wide rounded secondary ribs, and greatly enlarged anterior auricle. 

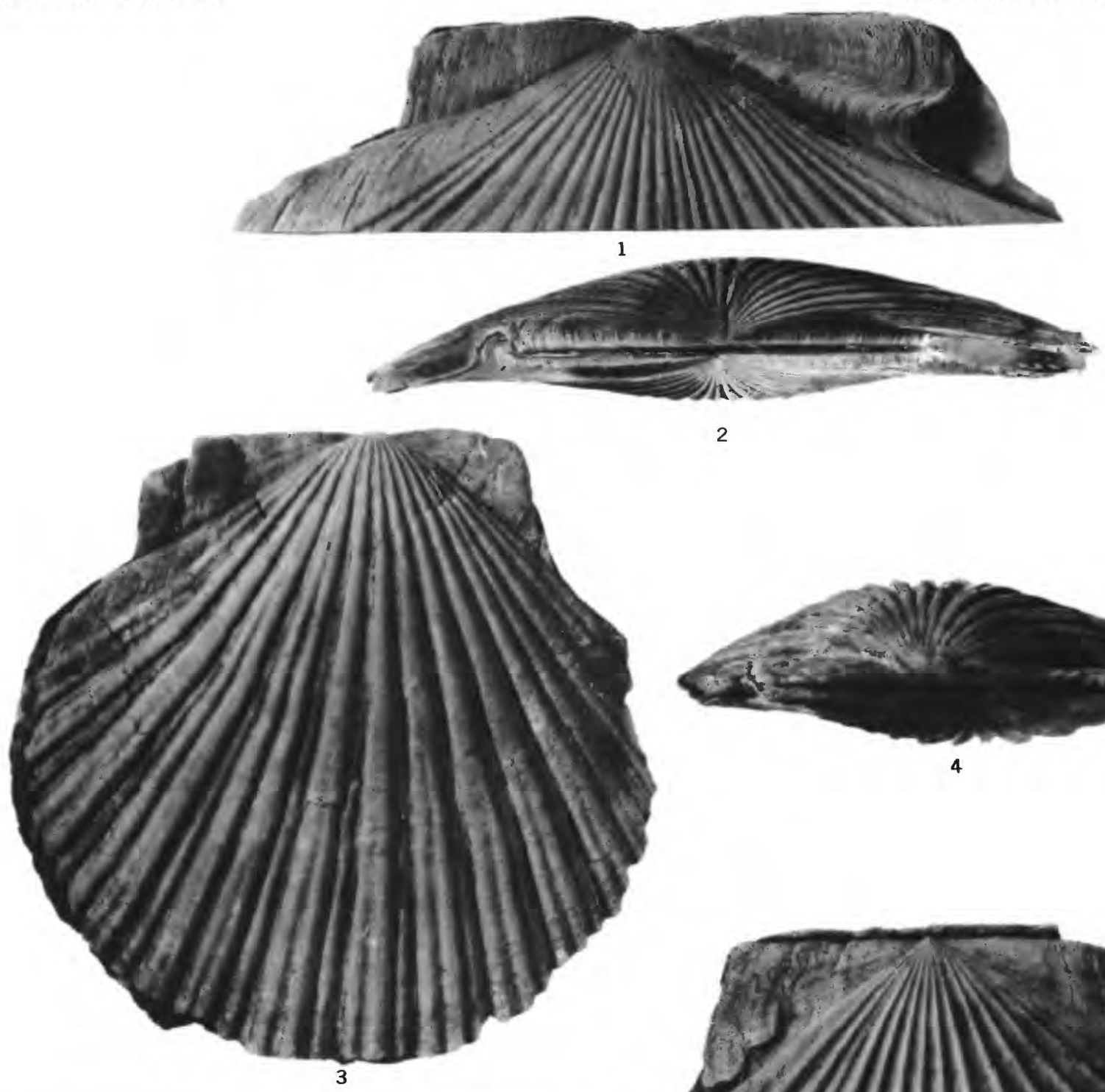

2
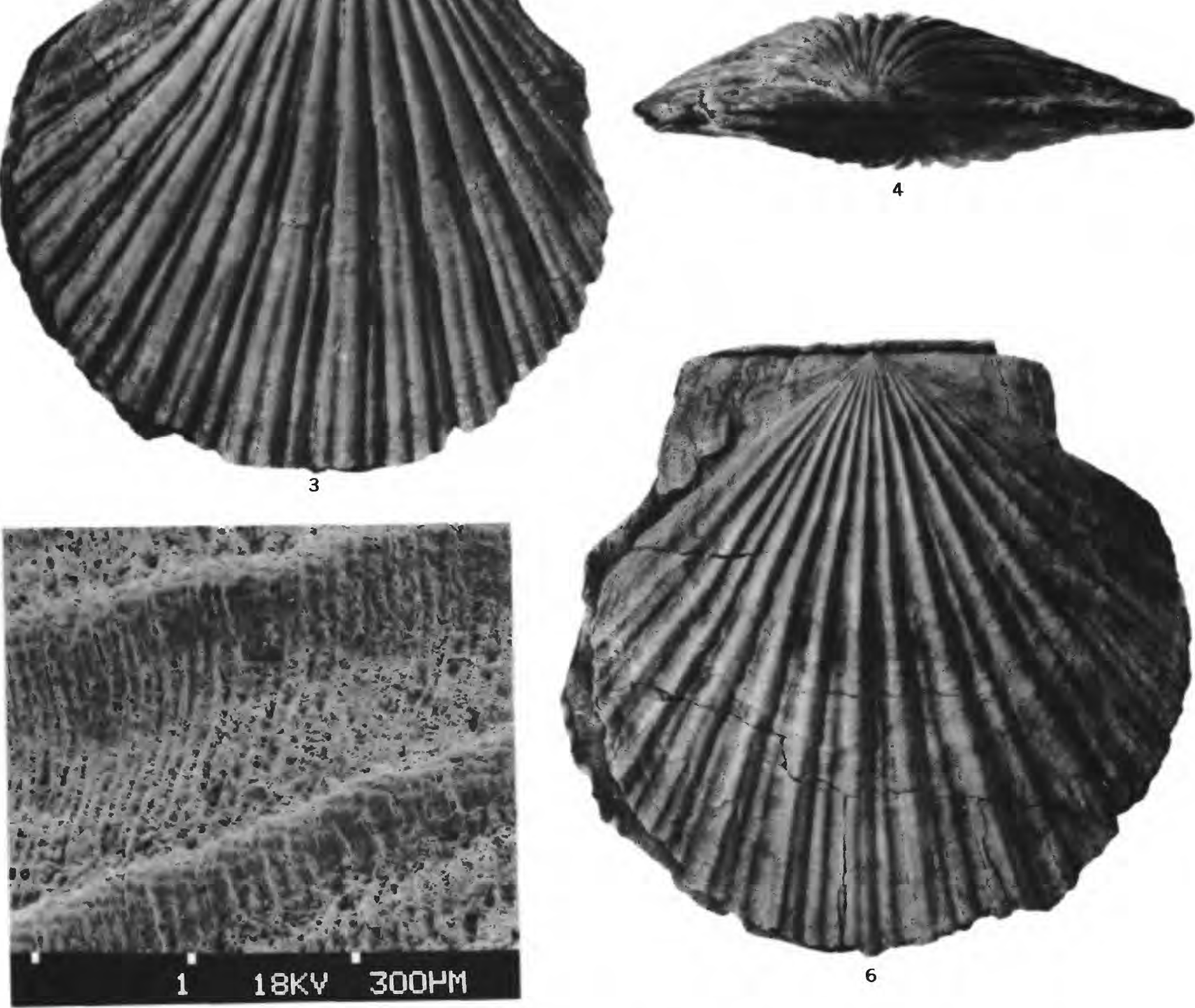

4

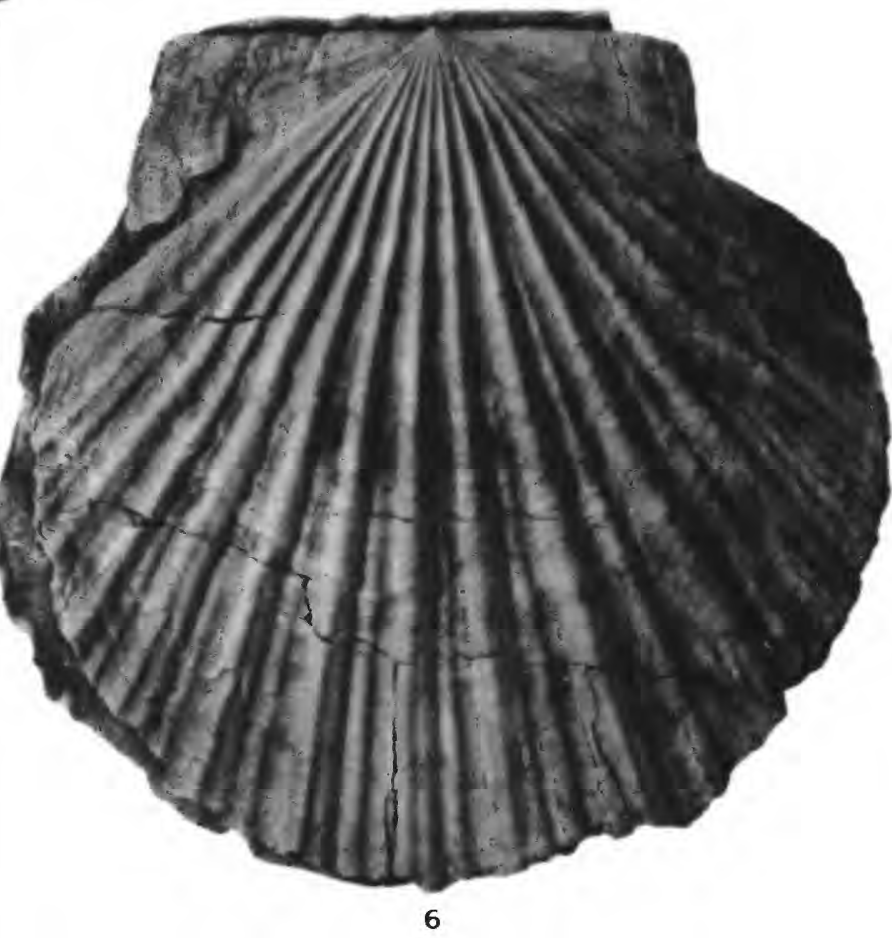

5

PATINOPECTEN HEALEYI (ARNOLD) AND PATINOPECTEN LOHRI (HERTLEIN) 


\section{PLATE 14}

Figure 1. Patinopecten yessoensis (Jay), Rikuoku, Japan. Exterior of right valve enlarged to show imbricated microsculpture. $140 \mathrm{~mm}$ high; $148 \mathrm{~mm}$ wide; hinge $77 \mathrm{~mm}$ long. SU loc. 1605. CAS $58773, \times 1.50$.

2, 3. Patinopecten healeyi (Arnold), San Diego Formation, San Diego, Calif.

2. Exterior of left valve enlarged to show imbricated microsculpture. 51.7 $\mathrm{mm}$ high; $52.1 \mathrm{~mm}$ wide; hinge $22.9 \mathrm{~mm}$ long. LAM loc. 107. LAM 5255, $\times 3$.

3. Exterior of right valve of largest double-valve specimen seen in any collection showing folded byssus of right auricle and large overlap of left anterior auricle. (Left valve of same specimen figured, pl. 15, fig. 3; hinge figured, pl. 13, fig. 2; pl. 15, fig. 2.) $190 \mathrm{~mm}$ high; $210 \mathrm{~mm}$ wide (broken at margins); hinge $95 \mathrm{~mm}$ long. LAM loc. 107. LAM 5254, $\times 0.75$ 

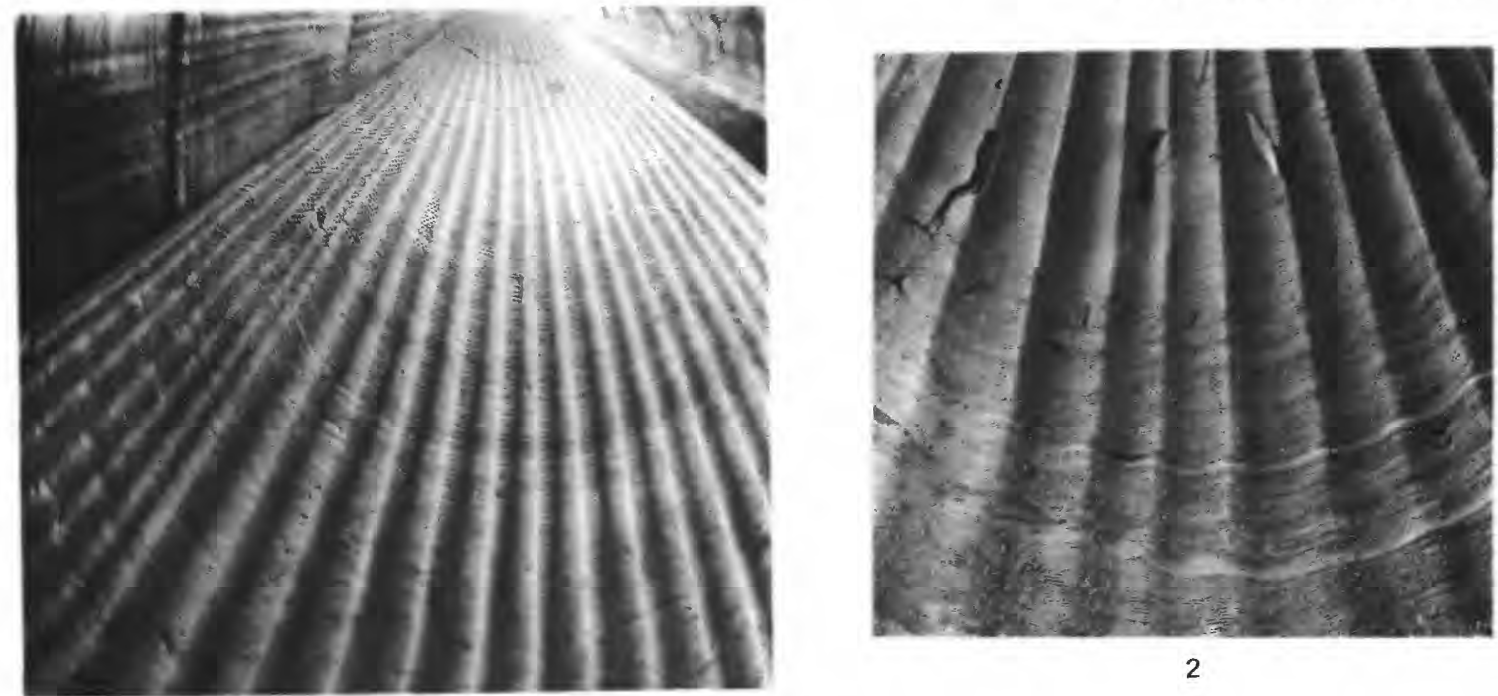

2

1

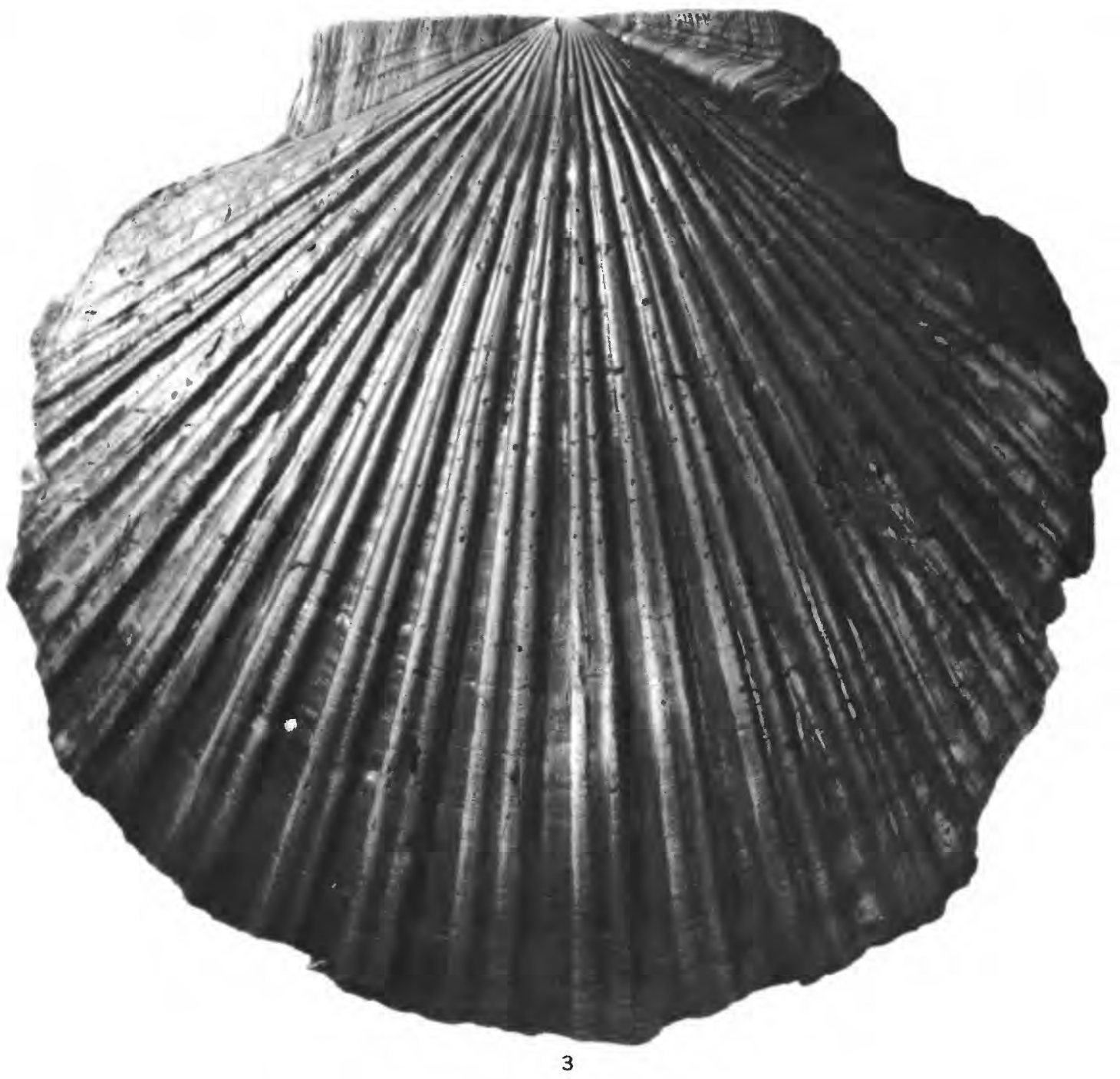

PATINOPECTEN YESSOENSIS (JAY) AND PATINOPECTEN HEALEYI (ARNOLD) 


\section{PLATE 15}

Figure 1. Patinopecten yessoensis (Jay), Holocene, Rijuoku, Japan. Exterior of left valve enlarged to show imbricated microsculpture. $140 \mathrm{~mm}$ high; 148 $\mathrm{mm}$ wide; hinge $77 \mathrm{~mm}$ long. SU loc. 1605 . CAS 58774, $\times 1.5$

2, 3. Patinopecten healeyi (Arnold), San Diego Formation, San Diego, Calif.

2. Exterior of hinge of left valve showing fold of anterior auricle. (Same specimen illustrated as fig. 3 ; right valve illustrated, pl. 14, fig. 3.) Hinge $95 \mathrm{~mm}$ long. LAM loc. 107. LAM 5254, $\times 0.75$

3. Exterior of left valve of the largest double-valve specimen seen in any collection showing overlap of larger valve along the margins. (Right valve of same specimen illustrated, pl. 14, fig. 3.) LAM loc. 107. LAM $5254.185 \mathrm{~mm}$ high; $205 \mathrm{~mm}$ wide; hinge $95 \mathrm{~mm}$ long, $\times 0.75$. 

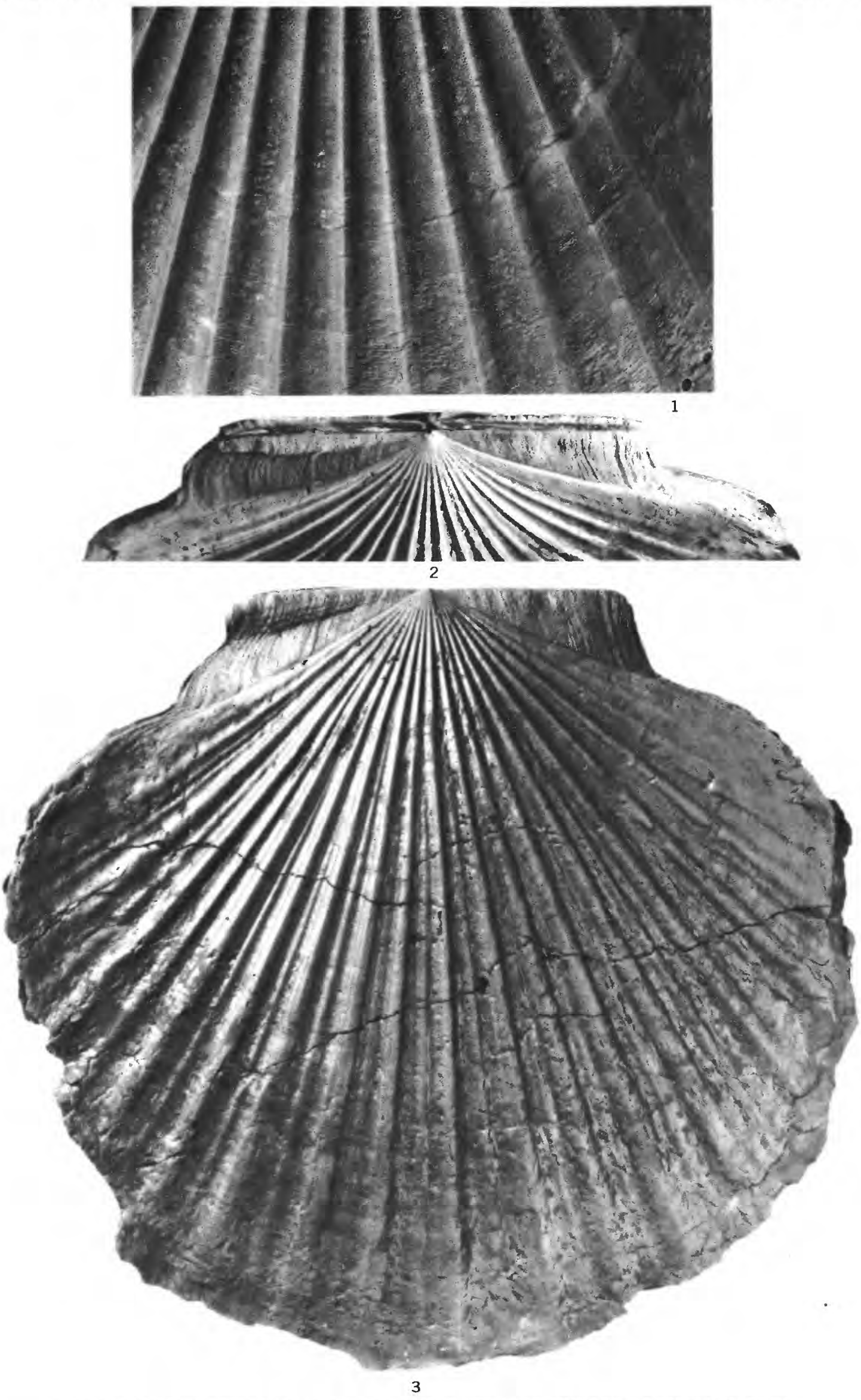

PATINOPECTEN YESSOENSIS (JAY) AND PATINOPECTEN HEALEYI (ARNOLD) 